\title{
Evidence for Late Messinian seismites, Nijar Basin, south-east Spain
}

\author{
A. R. FORTUIN* and C. J. DABRIO† \\ *Sedimentology Group, Faculty of Earth and Life Sciences, Vrije Universiteit, De Boelelaan 1085, 1081 \\ HV Amsterdam, The Netherlands (E-mail: anne.fortuin@falw.vu.nl) \\ $\dagger$ Departamento de Estratigrafia \& Instituto de Geologia Económica-CSIC, Universidad Complutense, \\ 28040-Madrid, Spain
}

\begin{abstract}
The Feos Formation of the Nijar Basin comprises sediments deposited during the final stage of the Messinian salinity crisis when the Mediterranean was almost totally isolated. Levels of soft-sediment deformation structures occur in both conglomeratic alluvial sediments deposited close to faults and the hyposaline Lago Mare facies, a laminated and thin-bedded succession of whitish chalky marls and intercalated sands alternating with non-marine coastal plain deposits. Deformation structures in the coarse clastics include funnel-shaped depressions filled with conglomerate, liquefaction dykes terminating downwards in gravel pockets, soft-sediment mixing bodies, chaotic intervals and flame structures. Evidence for soft-sediment deformation in the fine-grained Lago Mare facies comprises syndepositional faulting and fault-grading, sandstone dykes, mixed layers, slumping and sliding of sandstone beds, convolute bedding, and pillar and flame structures. The soft-sediment deformed intervals resemble those ascribed elsewhere to seismic shaking. Moreover, the study area provides the appropriate conditions for the preservation of deformation structures induced by seismicity; such as location in a tectonically active area, variable sediment input to produce heterolithic deposits and an absence of bioturbation. The vertical distribution of soft-sediment deformation implies frequent seismic shocks, underlining the importance of seismicity in the Betic region during the Late Messinian when the Nijar Basin became separated from the Sorbas Basin to the north. The presence of liquefied gravel injections in the marginal facies indicates strong earthquakes $(M \geq 7)$. The identification of at least four separate fissured levels within a single Lago Mare interval suggests a recurrence interval for large magnitude earthquakes of the order of millennia, assuming that the cyclicity of the alternating Lago Mare and continental intervals was precession-controlled. This suggestion is consistent with the present-day seismic activity in SE Spain.
\end{abstract}

Keywords Lago Mare, liquefaction structures, Messinian, Nijar Basin, palaeoseismology, seismites, soft-sediment deformation.

\section{INTRODUCTION}

Seismites are strata interpreted as having been deformed by earthquakes (Seilacher, 1969, 1984) and are therefore important as indicators of past seismic activity (Sims, 1973, 1975; Hempton \& Dewey, 1983; Ringrose, 1989; Obermeier, 1996). The main process driving deformation is liquefaction, the temporary transformation of granular material from a solid to a liquid state following an increase in pore water pressure and reduction in effective stress. Fluidization occurs when the drag exerted by moving pore fluids exceeds the effective weight of the grain so that sediment transport takes place, resulting in water-escape structures (Lowe, 1975).

Liquefaction is known to be triggered by seismic shaking. In sandy sediments, the minimum 
earthquake magnitude to form liquefaction features is about moment magnitude $M=5.5$ (Obermeier, 1996), but they become common in case of magnitudes above 6.6 (Ambraseys, 1988; Obermeier et al., 2005). Most liquefaction and flowage features occur within $15 \mathrm{~km}$ wide zones along observed tectonic structures (Kanaori et al., 1993), and empirical relationships between both earthquake intensity and magnitude and the area over which liquefaction takes place for historical earthquakes in Italy have been established by Galli (2000). According to these data the threshold for liquefaction near the epicentre is magnitude 4.2 with liquefaction of sands over $50 \mathrm{~km}$ away for magnitudes exceeding 6.5. During the 1964 Alaska earthquake $(M=9 \cdot 2)$, remobilization of sands and silts caused liquefaction damage as far as $130 \mathrm{~km}$ from the earthquake epicentre (Obermeier, 1996). Liquefaction is less commonly observed in gravels because of the increased resistance to shearing in combination with high permeability. The threshold magnitude to induce liquefaction effects in the most susceptible gravel deposits is 7 (Obermeier, 1996).

Geotechnical studies have shown that failure of sediment induced by seismic shocks is especially common where a more competent upper layer overlies a weaker, less competent lower layer. Syndepositionally deformed strata are frequently encountered in the fill of non-marine tectonically active basins (Ricci Lucchi, 1995; Rodriguez Pascua, 1997; Rodríguez-Pascua et al., 2000), particularly in non-burrowed, laminated sediments such as those occurring in the deeper parts of seasonally influenced lakes. Besides deforming bedding structures, seismic shaking is often accompanied by ground cracking and tensional failure parallel to complementary shear fractures. The most severe ground cracking occurs in low-lying active floodplains, where the water table is usually less than $3 \mathrm{~m}$ below the surface (Davenport, 1994). Experimental studies (Nichols et al., 1994; Moretti et al., 1999) have helped to demonstrate the relationship between the style of deformation and the intensity of ground shaking.

In older successions, relating soft-sediment deformation (SSD) to a seismic trigger remains a significant challenge as it is known that other processes, such as storms or gravity remobilization, may produce similar structures. The problem has been addressed by many authors (Sims, 1975; Ricci Lucchi, 1995; Obermeier, 1996; Bowman et al., 2004; Obermeier et al., 2005; Moretti \& Sabato, 2007) and various field criteria have been suggested to test a possible seismic origin for the observed structures.

The present study focuses on SSD features preserved in the Upper Messinian Feos Formation of the Nijar Basin, SE Spain. This basin is one of a mosaic of Neogene basins in the internal part of the Betic Cordilleras (Fig. 1). The Feos Formation in the northern part of this basin offers a unique opportunity for the study of SSD structures because of a fortuitous combination of tectonic and environmental factors. Firstly, deformation can be linked to a period of tectonism that separated the Nijar Basin from the Sorbas Basin to the north. Secondly, the heterolithic, nonburrowed Lago Mare deposits have a high potential to preserve seismites as they closely mimic deeper lake deposits that are known to be particularly susceptible to deformation. Thirdly, deposition of the Feos sediments was controlled by astronomically forced climatic conditions (dry-wet), causing base-level changes in the highly restricted Late Messinian Mediterranean (Fortuin \& Krijgsman, 2003). This process resulted in an alternation of heterolithic, thinbedded brackish-lacustrine deposits, representing the so-called Lago-Mare facies with coarsergrained continental deposits. The often wellexposed and laterally correlated sections enable interpretations about the possible lateral extent and/or lateral changes of the deformation structures.

In summary, the aim of this study was to present for the first time and to describe the context, character and lateral distribution of wellexposed SSD structures in the northern Nijar Basin, discussing their origin within the framework of a tectonically active region and a time of astronomically forced climate changes that strongly controlled sedimentation.

\section{REGIONAL SETTING}

The Neogene tectonic evolution of SE Spain reflects the ongoing interaction between the African and European plates. Early compression gave way to later extension and strike-slip deformation. The Miocene to Recent history of the intramontane basins is characterized by both vertical movements of blocks (Martinez-Diaz \& Hernandez-Enrile, 2004; Marín-Lechado et al., 2005) and associated strike-slip motions (Montenat et al., 1987a, Montenat \& Ott d'Estevou, 1999; Jonk \& Biermann, 2002) producing a basin and range topography. The main basins were 


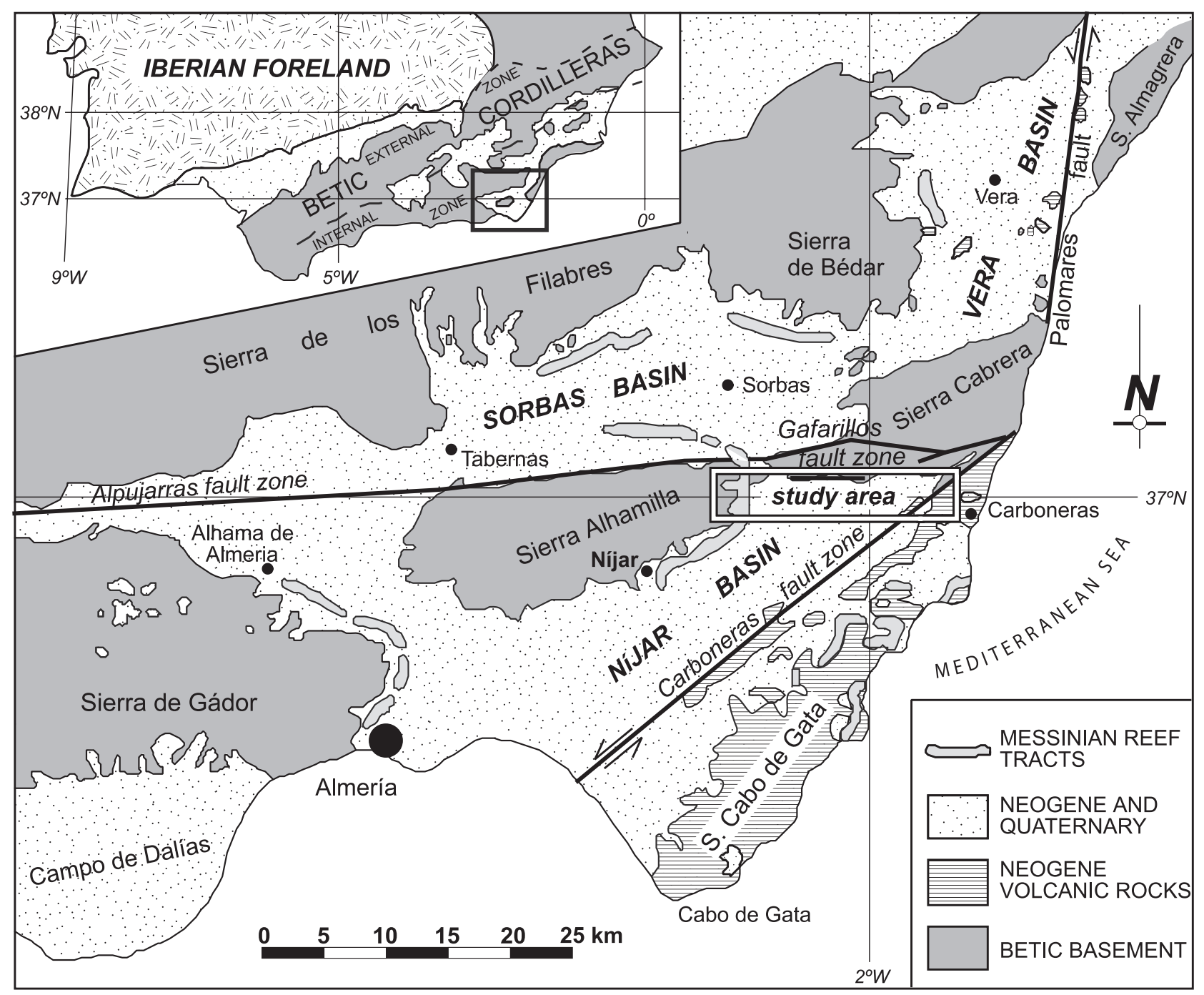

Fig. 1. Location map showing part of the internal zone of the Betic Cordilleras (inset) with the study area in the northern part of the Nijar Basin and its position related to the adjacent Sorbas and Vera Basins, plus the major fault zones that were active during the Neogene.

initiated during the Serravallian ( $c a 12 \mathrm{Ma}$; Montenat et al., 1987a). These basins preserve a unique record of sedimentary and biotic changes induced by disconnection of the Atlantic and Mediterranean during the Late Miocene, culminating in the Messinian salinity crisis (MSC), a period of extensive evaporite deposition and subsequent Lago Mare facies throughout the Mediterranean Basin (Hsü et al., 1977; Cita, 1982; Cita \& McKenzie, 1986; Cita \& McKenzie, 1986; Rouchy \& Saint Martin, 1992; Krijgsman et al., 1999; Rouchy \& Caruso, 2006). Isolation of the Mediterranean was probably controlled by a combination of tectonic, eustatic and climatic factors (Weijermars, 1988; Clauzon et al., 1996; Krijgsman et al., 1999). The tectonic evolution of the entire Betic-Rif orogen has been related to east-dipping subduction with westward slab roll- back of oceanic lithosphere beneath the Alboran Sea. Westward roll-back is interpreted to have ended around the Miocene-Pliocene boundary (Gutscher et al., 2002; Duggen et al., 2004), or slightly earlier, around 8 Ma (Jolivet et al., 2006). The latter authors argue that the Late Messinian closure of the Rifian and Betic gateways was a consequence of renewed compression after gravitational potential energy had been released, rather than slab retreat. Because plate tectonic convergence between African and Betic lithosphere has continued since the Late Miocene (Martinez-Diaz \& Hernandez-Enrile, 2004), the present neotectonic setting extends back to the Messinian interval discussed here.

Modern seismic activity in the Alboran region is of low to moderate magnitude with less frequent large earthquakes (Marín-Lechado et al., 
2005). At least 50 destructive earthquakes have affected the Alboran region during the past two millennia; this means that the sedimentary basins have a high seismite potential and seismites have been described from the Recent (Alfaro et al., 1999; Reicherter \& Reiss, 2001; Reicherter et al., 2003), Messinian and Pliocene of the Moroccan Rif (Machour et al., 1993; Plaziat \& Ahmamou, 1998) and the Late Miocene of the Pre-Betic zone (Rodríguez-Pascua et al., 2000). However, not all synsedimentary deformations in the Betic basins are seismites. A case in point is the Messinian 'seismites' reported in the San Miguel de Salinas Basin (Montenat, 1980) that have been re-interpreted as storm wave-induced deformation (Alfaro et al., 2002), an interpretation recently refuted by Montenat et al. (2007).

Fault kinematic studies indicate that the morphology of the internal Betic basins was largely controlled by the re-orientation of regional compressive stresses and their interaction with the main faults crossing the SE Iberian Peninsula (Montenat et al., 1987a,b; Coppier et al., 1990; Stapel et al., 1996; Huibregtse et al., 1998; Montenat \& Ott d'Estevou, 1999; Jonk \& Biermann, 2002). Three major strike-slip zones are important (Fig. 1): (i) the offshore NE-SW oriented sinistral Trans-Alboran Shear (de Larouzière et al., 1988) and its onshore continuation, the Carboneras fault zone (CFZ) which forms the NW boundary of the dominantly volcanic Cabo de Gata massif; (ii) the large west to east-trending dextral Alpujarras fault zone (AFZ; Martinez-Diaz \& Hernandez-Enrile, 2004) and its eastward extension along the northern margin of Sierra Alhamilla, into Sierra Cabrera known as the Gafarillos fault zone where it intersects the CFZ; and (iii) the NNE-SSW orientated, sinistral Palomares fault which was particularly active during the Messinian (Jonk \& Biermann, 2002; Booth-Rea et al., 2003). During the Tortonian, compression with a NW-SE orientation caused mainly dextral displacements along the west to east-orientated faults, such as the Gafarillos fault zone. In contrast, a clockwise rotation of the compressional stress to north to south during the Messinian drove sinistral displacements on the NNE-SSW to NE-SW trending faults. Of these, the Carboneras and Palomares faults played a key role in the history of the Nijar and Sorbas Basins by causing differential uplift of flanking basement rocks, especially the Sierra Cabrera.

The study area lies in the northern part of the Nijar Basin (Fig. 2) between the uplifted Sierra Alhamilla in the west, the Sierra Cabrera to the north and the sinistral Carboneras fault zone to the SE. In addition, a series of subordinate west to east-orientated faults delimit the southern margin of Sierra Cabrera. The Messinian and Lower Pliocene rocks are folded close to the basin margin fault zones, but this deformation decreases towards the basin centre. Also, common minor faults in the study area showing horizontal slickensides testify to the overall transpressional tectonic deformation.

\section{STRATIGRAPHIC FRAMEWORK}

The well-studied Sorbas and Nijar Basins together contain one of the most complete landbased Messinian successions in the Mediterranean. The oldest deposits (Azagador Member; Fig. 3) either directly onlap the metamorphosed basement rocks, or unconformably overlie older Tortonian strata. Prior to the onset of the MSC, open marine conditions prevailed in the thenconnected Nijar and Sorbas Basins (Abad Member and the upper Abad lateral reefal equivalent, the Cantera Member; Fig. 3). Differential uplift since the Late Messinian (Fortuin \& Krijgsman, 2003) caused the progressive separation of the two basins, with estimated minimum average uplift rates of $170 \mathrm{~m} \mathrm{Myr}^{-1}$ (Braga et al., 2003). After the basal Pliocene restoration of open marine connections, the centre of the Sorbas Basin was briefly invaded by a shallow marine sea (top level Zorreras Member; Fig. 3), but then emerged to become non-marine through to the present (Gochar Formation; Fig. 3). In contrast, marine conditions persisted longer in the Nijar Basin, approximately until the beginning of the Late Pliocene (Van de Poel, 1992, 1994; Cuevas and Molata Formations; Fig. 3). SSD structures are found within the upper Abad Member, the Sorbas Member and the Feos Formation (Fig. 3). (For details of the Messinian evolution of the two basins refer to Van de Poel, 1994; Martín \& Braga, 1994; Mather et al., 2001; Fortuin \& Krijgsman, 2003; Bassetti et al., 2006.)

Astronomical dating of the pre-MSC and the post-MSC deposits places the salinity crisis between 5.96 and 5.33 Ma (Lourens et al., 1996; Krijgsman et al., 1999, 2002). The astrochronological timeframe for the Messinian of the Sorbas Basin (Krijgsman et al., 2001) suggests that, after the formation of upward-shoaling, gypsum-bearing cycles (Yesares Member) in the basin centre, a desiccation interval occurred around 5.67 to 5.52 Ma. During this interval, the three to four 


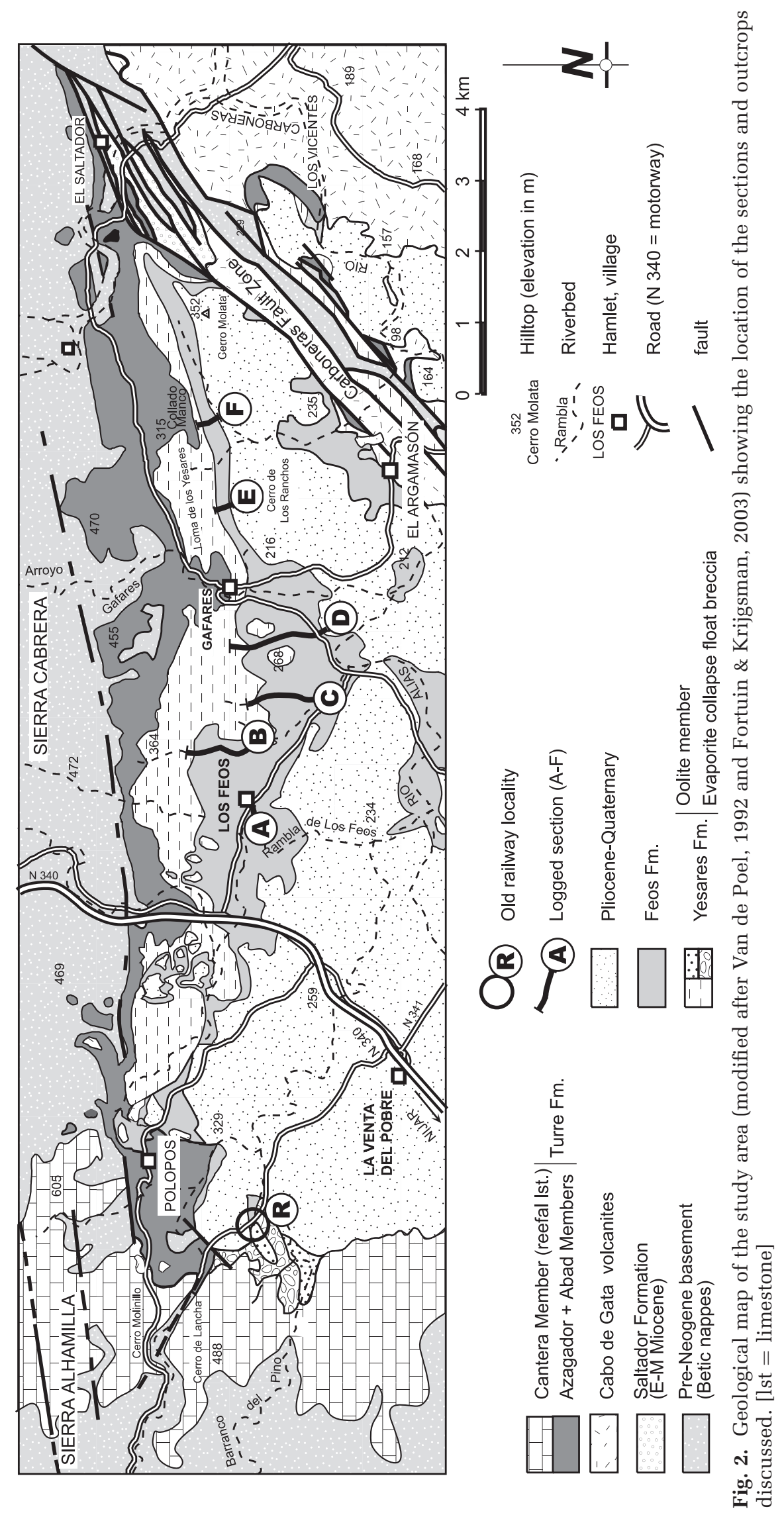


Góchar Fm.

PLIOCENE

Fluvial conglomerates
Molata Fm.

Fan-deltaic conglomerates

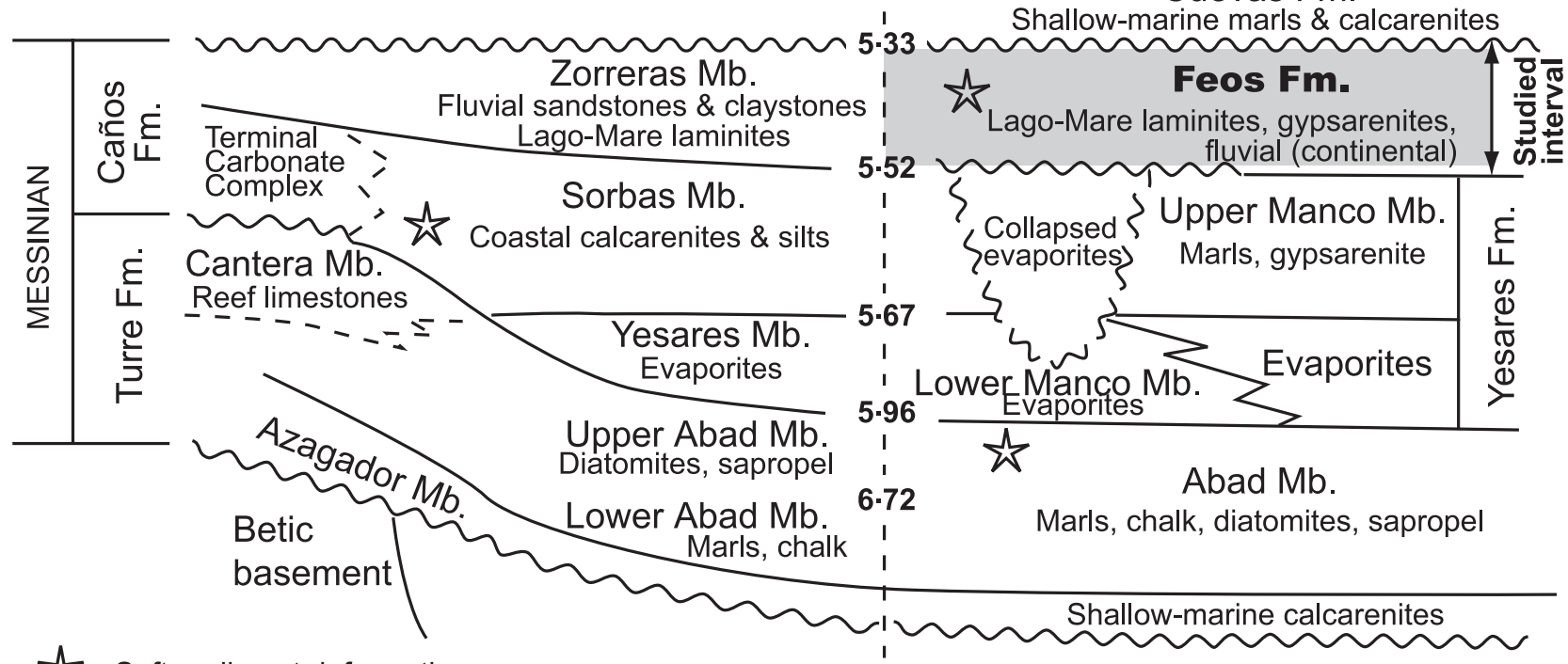

\section{放 Soft-sediment deformation}

Chozas Fm. / Betic basement

\subsection{Astrochronology ages (millions of years)}

Fig. 3. Stratigraphic framework of the Sorbas and Nijar Basins. The basins were interconnected during Early Messinian times, but became progressively more isolated by differential uplift and emergence of Sierra Cabrera during the Late Messinian. The ages indicated in 'Ma' follow the astrochronological ages given by Krijgsman et al. (1999, 2002).

cycles of the Sorbas Member (Roep et al., 1998) and Upper Manco Member accumulated in the Sorbas and Nijar Basins, respectively (Fig. 3). Oogonia of the green alga Chara found in laminated marls of the Upper Manco Member indicate that freshwater to brackish conditions were already established just before deposition of the Feos Formation, the focus of the present study.

The Feos Formation (up to $110 \mathrm{~m}$ thick) was deposited between 5.52 and 5.33 Ma (Fig. 3). It consists of a cyclic arrangement of whitish to grey chalks, marls and sandstone layers alternating with varicoloured, mud-rich to coarse-grained continental strata that can be traced laterally to the northern limit of the Nijar Basin (Fig. 4). The heterolithic association of often laminated and thin-bedded marls and sands (informally called 'laminites', following Rodríguez-Pascua et al., 2000) represents the Late Messinian Mediterranean-wide Lago Mare facies. It includes oligohaline and stenohaline faunal elements, such as the green alga Chara sp., the benthic foraminifer Ammonia tepida and the ostracod Cyprideis pannonica. Rare euhaline marine foraminifera found in some layers suggest temporal openmarine conditions (Aguirre \& Sánchez-Almazo,
2004; Bassetti et al., 2006), but these are probably mostly reworked as they occur together with planktonic foraminifera characteristic of Lower Messinan deposits, or showing evidence of wear (Van de Poel, 1992; Fortuin \& Krijgsman, 2003; Bassetti et al., 2006). Periodic terrestrial conditions can be inferred from the presence of red and grey calcrete-rich weathering profiles (palaeosols), coarse clastic channel-fills and debris flow deposits. In total, the Feos Formation includes seven to eight cycles of Lago Mare deposits shoaling into continental strata (Fig. 4), each recording a fluctuation in the Late Messinian base level. The cycles probably represent climatic oscillations that caused changes in the water budget and water level in the, at that time, isolated Mediterranean (Fortuin \& Krijgsman, 2003; Bassetti et al., 2006).

Along the NW margin of the Nijar Basin, bordering the Sierra Alhamilla, the oldest Feos strata are dominantly coarse-grained terrestrial clastics (conglomerates and sandstones) and these contain common liquefaction structures. NE of Los Feos hamlet (Fig. 2), the base of the Feos Formation is an erosional unconformity, separating Yesares evaporites from gypsum-rich conglomerates and 


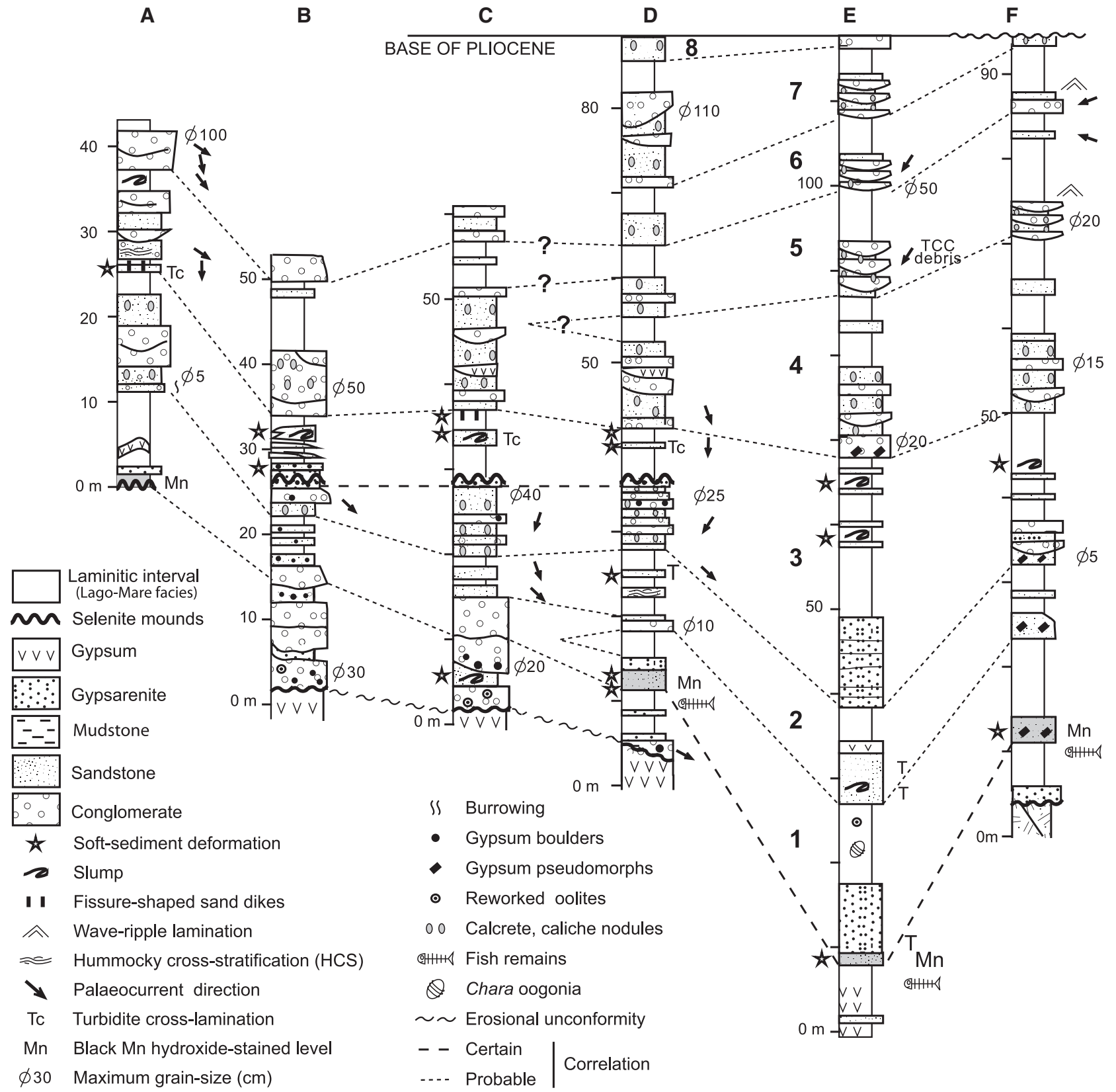

Fig. 4. East-west correlation diagram showing schematically the logged Feos sections (A to F) along the southern flank of Sierra Cabrera (modified and upgraded after Fortuin \& Krijgsman, 2003). For location of the sections, see Fig. 2. The numbers left of section $\mathrm{E}$ indicate the succession of depositional cycles as formed by a basal, dominantly coarser clastic (or gypsarenitic) interval, followed by marly, often laminitic Lago Mare sediments. Levels with softsediment deformation attributed to seismic activity are indicated with a star.

associated fines. This erosional contact becomes conformable to the SE and east, where the lower part of the Feos Formation is also characterized by the presence of gypsum-rich turbiditic sandstones and siltstones. Here, the boundary with the underlying Yesares Formation is marked by a distinctive, dark coloured Mn-hydroxide-impregnated level
(Fig. 4). There is a gradual, but distinct, deepening trend towards the east, expressed by an overall decrease of clastic grain-size and bed thickness, and a more distal aspect of the turbiditic interbeds. Many of the gypsarenites become finer-grained and well-graded in the east. Moving in a NW-SE direction, there is a change in the overall palaeocurrent 
pattern: measurements (Fig. 4) indicate SE, south and even SW dispersal in the youngest, easternmost outcrops close to the CFZ.

Most of the Feos Formation outcrops studied occur in roughly north to south-orientated dry flood channels. These logged sections, labelled A to F (Figs 2 and 4), are situated east of motorway A340 (but access roads branch off from motorway N340). The intervals showing the most extensive SSD are Lago Mare sections exposed between the ruined hamlet of Los Feos and Gafares. In addition, outcrop R, situated in the north-western part of the study area (Fig. 2), exposes a gravelly, terrestrial interval with abundant liquefaction features. This former railroad cut is presently a dirt track starting at La Venta del Pobre.

\section{SOFT-SEDIMENT DEFORMATION IN SANDY AND CONGLOMERATIC BASIN-MARGIN DEPOSITS}

Syndepositional deformation related to active faulting is very well-exposed along a two-sided road-cut (position $37^{\circ} 01566^{\prime} \mathrm{N} ; \quad 02^{\circ} 09187^{\prime} \mathrm{W}$ ), $1.5 \mathrm{~km}$ SW of the hamlet of Polopos (outcrop R; Fig. 2). This NW basin margin location is situated where the north to south reef trend delimiting the eastern margin of Sierra Alhamilla passes into the stronger uplifted reef trend at the western end of Sierra Cabrera. Various larger faults cross the area, such as a well-exposed NE-SW orientated reverse fault within a kilometre northwards from this location (Fig. 2). A west to east-orientated fault separates this road-cut from Pliocene deposits further north.

\section{Outcrop description}

The outcrop, a former railroad-cut through a small hill, is $60 \mathrm{~m}$ long, up to $6 \mathrm{~m}$ high and orientated NNW-SSE (Fig. 5). Approximately $8 \mathrm{~m}$ of west-dipping continental coarse clastics are exposed here, overlying basal (fault-bounded) medium-bedded sandstones and mudstones, just visible at the $\mathrm{NE}$ corner of the outcrop, and overlain by poorly preserved whitish Lago Mare fines at the top of the hill. These lithologies are similar to the basal Feos continental intervals exposed further east towards motorway N340 and beyond (Fig. 2), but the many secondary (strikeslip) faults in the intervening area hinder bedto-bed correlation.

The structure of this outcrop is that of a small domal anticline, obliquely cut by two sub-paral- lel, minor faults with orientations of $\mathrm{N} 120^{\circ} \mathrm{E}$ and N103 ${ }^{\circ}$ E (Fig. 5). Preserved horizontal slickensides indicate strike-slip offset. These faults sub-divide the outcrop into three compartments informally called A (north), B (central) and C (south), suffixed 1 and 2 for the western and eastern sides of the cutting, respectively. The northern compartment $\mathrm{A}$ is situated close to a west to east-trending fault running just north of the outcrop and is separated from compartment B by another, minor WNW-ESE fault. Together, the compartments clearly show a northward increase in SSD (Fig. 5) related to water escape and liquefaction, with local injection and/or mixing of lithologies.

The stratal patterns within the three fault compartments on either side of the cut are slightly different. This variation is due to a combination of a low-angle westerly fold plunge, rapid facies changes and minor lateral offset by the bounding strike-slip faults. Three stacked in situ facies are present; they are best exposed in the eastern central compartment B-2 (Fig. 5). In ascending stratigraphic order, these are: Facies 1, pebbly mudstone: a chaotic mixture of angular to rounded fragments, including decimetre-sized often deformed mudlumps, embedded in a muddy matrix, such as in compartment A-1 (Fig. 5). Facies 2, pebbly sandstone: medium and coarsegrained sandstones, including a variable amount of sub-angular to rounded pebbles. Facies 3, conglomerate: poorly bedded, angular to subrounded gravels and conglomerates including thin sandy intervals and outsized boulders up to $80 \mathrm{~cm}$ in diameter. Grain-size variations define vague bedding. The clast composition consists of carbonate rocks, including Porites boulders and various types of metamorphic rocks. Between a distance of 20 and $25 \mathrm{~m}$ along the outcrop (compartment B-2; Fig. 5) a thick (>1 m) largescale cross-bedded set is present. The crossbedding and pebble imbrication indicate flow to the SE.

The entire setting is interpreted as deposited in an alluvial setting dominated by rapid supply of coarse clastics, initially settling from debris flows, followed by stream flow. The clast composition reflects reworking from the nearby exposed Sierra Alhamilla and its fringing pre-drawdown reefs of the Canteras Member (Fig. 2). The mud-rich diamictites of Facies 1 resemble pelitic, olistostrome-like float breccias described at the Yesares-Feos transition in this corner of the Nijar Basin (Fortuin \& Krijgsman, 2003; Fig. 3) and observed in erosional contact with underlying 
$\stackrel{\infty}{0}$.

3.

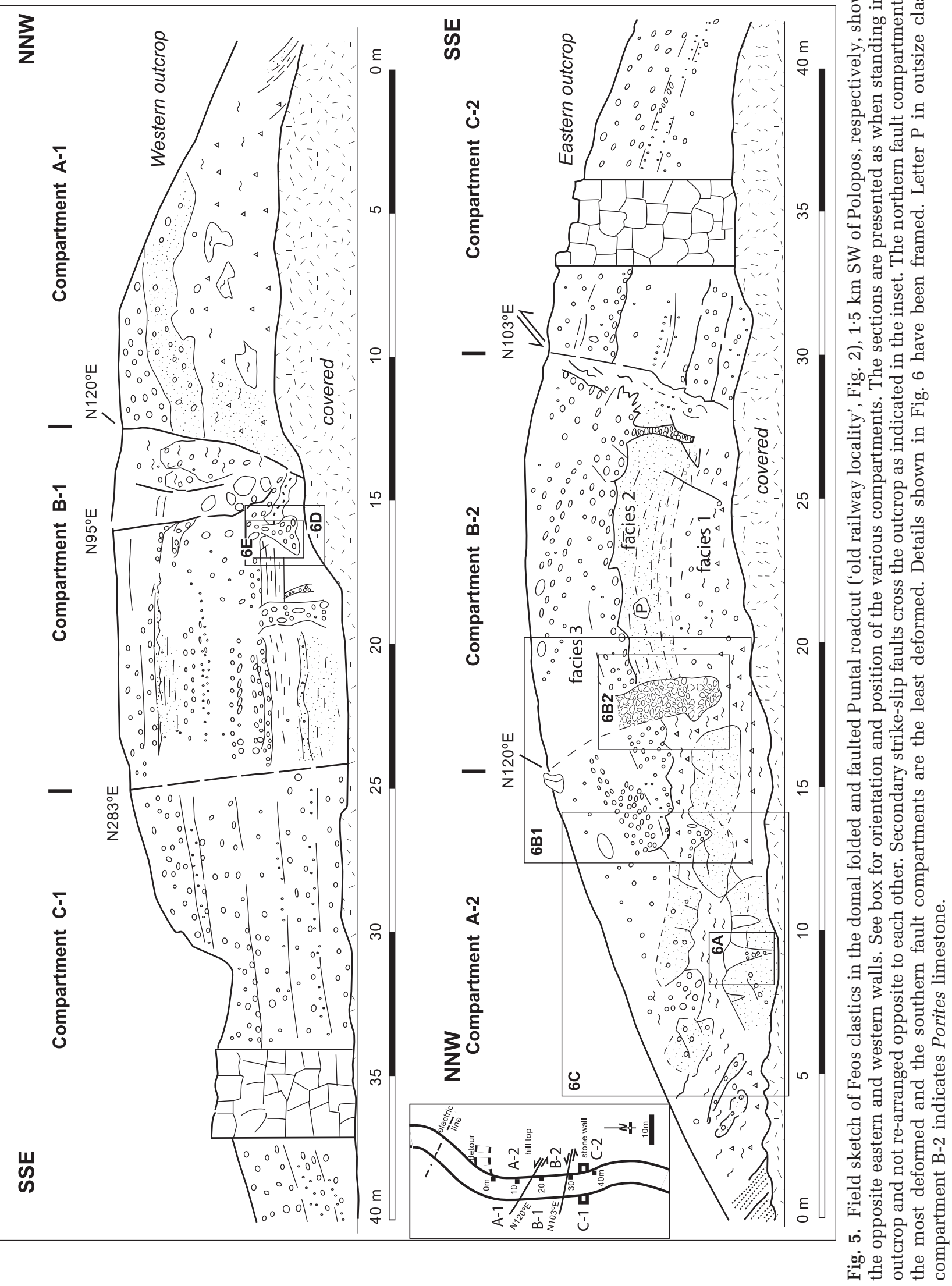


distal pre-drawdown reefal deposits. The latter authors interpreted these deposits to be a result of gypsum dissolution and collapse plus mass transport prior to deposition of the bulk of the Feos Formation. As such, Facies 1 could represent the transitional interval from such chaotic float breccias to normally stratified Feos deposits.

The southern compartments C-1 and C-2 contain an almost undisturbed southward-dipping conglomeratic succession, formed by four crudely bedded and graded sandstone-conglomerate sheets representing Facies 3. The beds include a large amount of reworked Messinian reefal clasts, up to $50 \mathrm{~cm}$ in diameter. Compartments B-1 and B-2 show an orderly succession of the three facies types, but here a number of vertical to oblique liquefaction dykes are present that are discussed in the next section. Within compartment A-2 the three facies are also present. Soft-sediment mixing has taken place, as shown by the southward doubling and partial mixing of Facies 1 and 2 (Fig. 5). Compartment A-1 consists mainly of chaotic pebbly mudstones of Facies 1 overlain by poorly delineated Facies 2 and 3 .

\section{Cone-like structures}

These are vertical funnel-shaped depressions filled from above with conglomerate as can be observed in the lower sandstone interval (Facies 2) of compartment A-2. The largest (1.2 m high) and best preserved example at a distance $8 \mathrm{~m}$ along the outcrop (Fig. 6A) has been modified by erosion but still preserves its conglomeratic contents. Its margin consists of a structureless gravelly sand which surrounds the remaining conglomeratic fill in the narrower, deeper part. The absence of stratigraphically older conglomerate in this outcrop indicates that this conglomeratic fill came from above, as also suggested by flat pebbles that are orientated parallel to the near-vertical contact. This observation implies that the process causing this feature was capable of liquefying overlying conglomerates which eventually resulted in the downward sagging of pebbles and cobbles. The absence of a conglomerate level directly above this cone structure is striking.

\section{Liquefaction dykes, terminating downwards in gravel pockets.}

In compartments B-1/B-2 several gravel dykes are present, penetrating into underlying, finergrained strata. In one case (compartment B-1 at $16 \mathrm{~m}$ in Fig. 5; Fig. 6E, D) penetrated sediment lateral to the dyke shows small reverse faults dipping away from the gravel pocket, suggesting associated compression. The undisturbed strata surrounding this injected material are finergrained and better sorted than the injected material. Because coarser clastics are only present higher up in the B-2 level an origin from a higher, coarser clastic level is indicated. Flat pebbles in an upright position also indicate realignment by downward-directed flow of liquefied gravel.

The larger gravel dykes occur close to the fault planes bordering compartment $\mathrm{B}$, suggesting a genetic relationship. The most prominent example is a downward penetrated gravel bulge over $1 \mathrm{~m}$ deep, located at $17 \mathrm{~m}$ (Figs 5 and 6, B-1 and $\mathrm{B}-2$ ) and flanking the minor fault trending $120^{\circ} \mathrm{E}$. Also at this location, downward infilling by liquefied coarse clastics, as present higher up, is indicated by flat pebbles re-aligned parallel to the vertical margin.

The other coarse clastic dykes, such as those present between a distance of 13 and $15 \mathrm{~m}$ in compartment B-2 and at $29 \mathrm{~m}$ in compartment B-2 (Fig. 5), are different in so far as they consist of up to more than $1 \mathrm{~m}$ wide chaotic zones. These zones are characterized by the presence of highly disorganized, mud-rich pockets comprising large boulders, positioned adjacent to normal stratified sediment, thus showing evidence for mixing of the different facies types and a re-oriented fabric.

\section{Chaotic strata}

In compartment A-2 the pebbly sandstone Facies 2 splits up in two levels of partly plastic, partly

Fig. 6. Photographs showing liquefaction structures in the Puntal roadcut. For location, see Figs 2 and 5 . (A) Remains of a funnel-shaped structure, filled from above with conglomerate, are still present near the hammer. The margin is a gravelly sand that has passed through a liquefied state. (B1) Downward pointing gravel bulge in the shape of an elephant foot (see detail in B2; hammer for scale) sitting near a minor fault plane trending $120^{\circ} \mathrm{E}$. Flat pebbles in an upright position indicate a downward infilling by liquefied coarse clastics present higher up. (C) Chaotic stratal pattern, with a pebbly sandstone interval crumpled and partly doubled northward, and pebbly mudstone facies extruded upward and laterally - marked with a yellow arrow. Hammers for scale. (D) Gravel sack in association with both plastic and brittle deformed surrounding beds. (E) Detail of brittle deformed margin of the sack shown in photograph (D), suggesting that brittle deformation occurred by hydraulic fracturing. The length of the hammer used for scale is $28 \mathrm{~cm}$. 

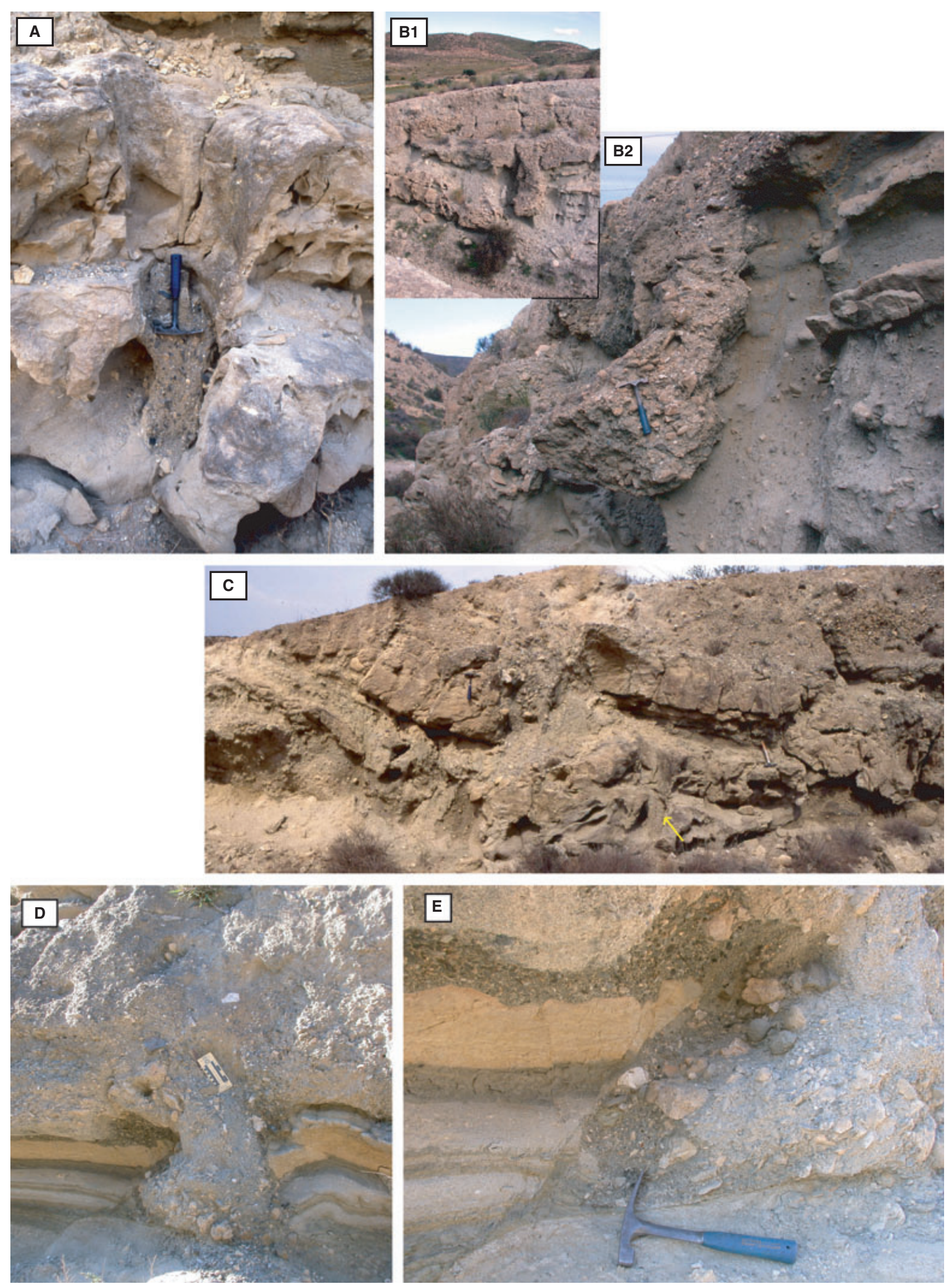
brittle deformed slabs, separated by a muddy interval (Figs 5 and 6C). Towards the periphery of this outcrop, these sands pass into chaotic Facies 1. At a distance of 7 to $8 \mathrm{~m}$ (Fig. 5), the upper sandstone level is abruptly interrupted by conglomerate, partly mixed with mud and located where this sandstone level bends downward. The lower sandstone level, at distance $12 \mathrm{~m}$ shows a similar abrupt bending, here associated with a small reverse fault. The underlying sediment is rich in small-scale (plastic) deformation structures.

\section{Small-scale gravel loads}

There are various examples of small-scale gravel loads such as those at the base of Facies 3 in compartment B-2 (visible just above the Porites clast labelled ' $\mathrm{P}$ ' in Fig. 5) and some minor flame structures in Facies 2. In one case, pebbly coarse gravel has loaded into a finer gravel forming a wedge around $30 \mathrm{~cm}$ across and dipping $30^{\circ} \mathrm{SSE}$.

\section{Interpretation}

This outcrop is important as it unambiguously shows a relationship between SSD and faulting. Part of this faulting probably occurred after deposition of the Feos Formation, as suggested by observed slickensides preserved in more consolidated sediment along the fault-orientated N103 ${ }^{\circ}\left(283^{\circ}\right) E$. Fault activity, however, seems to have started shortly after deposition of the coarse clastics, as suggested by the presence of up to $1 \mathrm{~m}$ wide zones along the two minor faults consisting of chaotic, mud-rich sediment with evidence for displaced boulders in pockets and a re-oriented fabric. This arrangement indicates the (possibly repeated) re-mobilization because of fluid escape when the sediment was still unconsolidated and water-filled. Because the position of this outcrop in a small, pushed dome, cut by strike-slip faults is consistent with the regional NNW-SSE orientated compression envisaged during the Messinian (Huibregtse et al., 1998), a genetic relationship of the structures observed with Late Messinian tectonic activity seems plausible. Late Messinian tectonic activity is also demonstrated by a nearby exposed angular unconformity separating Feos sediments from the overlying Pliocene deposits. Moreover, the position of the liquefaction features in the gravels and sands discussed here along minor faults suggests a relationship with tectonics and seismic shaking. Given the fact that the coarse clastics present here are lique- faction-resistant, a stratum of low permeability should have capped these deposits (Obermeier, 1996). The erosion relics for such a cap are still present as whitish, chalky Lago Mare facies covering the conglomerates nearby at the top of this hillock.

A significant feature of this locality is the northward increase in deformation from compartment $\mathrm{C}$ to $\mathrm{A}$. When comparing the more coherent compartment B-2 with A-2, it seems that the pebbly sandstone Facies 2 has been pushed northwards over and into the pebbly mudstone Facies 1. At the same time Facies 1 forms a chaotic wedge (between 14 and $18 \mathrm{~m}$ along the section in Fig. 5), separating the sandstone Facies 2 from the conglomerates of Facies 3. This development, in combination with the faults, suggests that tectonic compression induced a type of highly chaotic reverse faulting because of the still plastic character of the sediment. It is assumed that this complex situation did not yet exist when the gravel-filled cone-shaped structure (Fig. 6A) was formed; this is because the gravel that must have been supplied from above is presently not available.

This latter funnel-shaped depression, together with several less well-exposed examples in compartment A-2, resembles the 'draw-in' structures described by Takahama et al. (2000). Draw-in occurs immediately after the earthquake shocks have ceased, during the final stage of liquefaction. In this context the funnel-shaped outer sandy ring is explained as the result of the initial upward spouting of liquefied sediment. This stage was followed by the sagging of liquefied gravel and sand into the opened void. These funnel-shaped structures are thus interpreted to be older than the final deformation here.

The apparent stratigraphic position of the sediments discussed here on top of nearby exposed and up to $15 \mathrm{~m}$ thick chaotic floatstones may be important. These floatstones are restricted to this corner of the study area (Fig. 2) and are related to dissolution and collapse of evaporitic strata deposited at the basin margin in front of and above the distal parts of reefal clinoforms formed by progradation of the Messinian (pre-salinity crisis) reef tracts (Fortuin \& Krijgsman, 2003). These clinoforms are thought to have offered pathways for migration of phreatic waters that dissolved the juxtaposed evaporitic strata. This diamictic, olistostrome-like mass may have formed an unstable foundation when ground motions took place. A possibility, suggested by the upward movement and partial mixing of this 
material with the sandstone unit at the northern end of compartment A ( 2 to $6 \mathrm{~m}$ on the section shown in Fig. 5), is that the combination of seismicity and instability enabled the olistostrome-like mass to partly incorporate basal Feos deposits.

It could be argued that the features described are a direct result of dissolution and collapse of underlying sediments during deposition of the Feos strata. However, in this case, the chaotic zones along the fault planes should exhibit features derived from a combination of liquefaction and downward flow towards the deeperseated karst dissolution voids. The observed upward injection of the basal mud-rich breccia, in juxtaposition with the overlying and deformed pebbly sandstone facies in compartment A-1, however, points to tectonic compression with upward-directed sediment flow. Tectonic compression is also shown by the locally liquefied gravel fabric.

The presence of poorly cohesive pebbly sands (Facies 2) below the conglomerates (Facies 3) presumably increased their susceptibility to liquefaction. In segment B-1 a fluidization pillar occurs which terminates downwards in a gravel liquefaction pocket, surrounded by brittle deformed sand beds (Fig. 6D and E). Experimental studies on fluid-escape structures (Nichols et al., 1994; Moretti et al., 1999) show that, in case of fluid escape, catastrophic rupturing with upward expulsion of excess pore water takes place. In unconfined media the voids formed have a conical form and disrupted layers are bent upwards, i.e. they are seated within an antiformal structure. The margin seen in the liquefaction pocket (Fig. 6D) shows a more complex geometry, with gravel bordering a ruptured margin (see Fig. 6E for detail) plus folding and small reverse faults. Because the associated faults do not penetrate the gravel they must have originated before, or simultaneously with, the fluid escape. Such brittle deformation points to cohesive behaviour by which the sudden increase in pore water pressure is not enough to liquefy the sediment (Vanneste et al., 1999; Neuwerth et al., 2006). The compressional character of the brittle deformation in combination with the evidence for strike-slip faulting, as demonstrated by horizontal slickensides, suggests that it is essentially a flower structure and not a compaction feature. This combination of brittle behaviour with fluid escape can be interpreted either as the result of two superimposed events, or, more likely, the result of a single shock, in which the relatively high velocity of the shock front affected the variably consolidated sediment differently. Analogous combined brittle and ductile behaviour in soft-sediment deformed coarse clastics in the Late Miocene of the Spanish Prebetic Zone (Rodríguez-Pascua et al., 2000) has been interpreted as triggered by strong seismic shocks.

The overall indications for complex sagging and remobilization of the upper conglomerates along faults imply that the faults propagated to the surface to form ground cracks that evolved with repeated slip events. Sediment deformation structures in conglomerates associated with strike-slip deformation have also been described from the Plio/Quaternary basin fill of the nearby Sorbas Basin (Mather \& Westhead, 1993).

\section{SEISMITES IN THE BASINAL LAGO MARE FACIES}

\section{General setting}

The distinct cyclic alternation of reddish and greyish continental clastics and white to grey 'Lago Mare' (LM) mudstones and associated sandstone interbeds is well-developed east of the N340 motorway (Fig. 2). Here, in the lower parts of the succession, gypsrudites and gypsarenites form the coarse clastic cycle intervals. To the east (sections E and F, Fig. 4), these coarser clastic intervals (labelled 1 to 3 in Fig. 4) are characterized by the presence of gypsarenitic turbidites. Upwards, the overall cyclic pattern is maintained by an alternation of reddish to grey continental intervals and LM deposits. The relative proportion of sands and coarser clastics decreases to the east and south, following the overall south to SE palaeocurrent orientation. A typical LM sequence is up to $12 \mathrm{~m}$ thick. The regular alternation of continental and lagoonallacustrine LM facies indicates that the basin underwent repeated periods of desiccation and reflooding during this terminal part of the Messinian (Fortuin \& Krijgsman, 2003; Bassetti et al., 2006).

The finer-grained LM intervals consist of marly to chalky sediments with intercalations of very thin-bedded to medium-bedded, graded and wellsorted sand layers. Often varve-like bedding rhythms are developed (laminites). Lamination and other sedimentary structures are well-preserved because of the absence of bioturbation. Even the basal surfaces of very thin sand beds may show small-scale scouring of underlying 
marls, followed by a graded interval, thus indicating episodic sediment supply, probably associated with high discharge events in the basin, e.g. after storms or floods. Thin, distal Bouma Ta-c turbidite sequences are common. These mud-sand couplets thus form vertical permeability barriers, a basic requirement for potential triggering of fluid-escape processes. Vertical (and lateral) variations exist from dominantly mudrich to almost marly in the lower and middle part, to dominantly sandy at the top.

The vertical transition from LM facies to continental clastics is often rapid, expressed by both thickening-up and coarsening-up. Sandy top strata may include small-scale hummocky crossstratification (HCS). The overlying terrestrial strata include calcretic soils and sandstone/conglomerate layers. The occurrence of small-scale HCS can be explained as the result of storm action on the sandy tops of small offlapping deltaic sandstone bodies which accompanied the progressive draw down of Lago Mare waters. The features found in the terrestrial strata are interpreted as generated on braid plains with pedogenesis and episodic overwash by sheet flows and debris flows.

Sediment deformation is especially well-developed in the older cycles corresponding to the lower half of the formation. The deformed levels can be followed laterally for up to $8 \mathrm{~km}$ based on careful lateral tracing and detailed logging of sections (Fig. 4). Given the southward and eastward decline in grain-size and the observed palaeocurrent trend, some bottom gradients will have existed, the importance of which will be discussed later. Although individual LM units can be traced over significant distances (Fig. 4), where they contain several deformation horizons, unambiguous lateral correlation of these is more difficult. The most informative interval is cycle 3, as shown in Fig. 7B, because it comprises the best and most thickly developed LM sediments which can be confidently traced between Los Feos (section A, Fig. 4) and Collado del Manco (section F, Fig. 4) in the east. This interval is referred to here as 'Large Lago Mare interval' (LLM), with outcrop B (Figs 2 and 7B) as the type section.

Lateral variations in SSD can be studied by tracing the two most distinctive intervals: cycle 1, containing the dark-coloured Yesares-Feos manganese boundary level and the LLM unit (cycle 3, Figs 4 and 7B). The latter varies from sand-rich north of Los Feos (section B, Fig. 2) to the characteristic whitish LM marlstones in the more distal parts east of Gafares (sections $\mathrm{E}$ and F; Fig. 2). Its basal part, which starts above graded gypsrudites/arenites locally topped by small selenite mounds, is poor in sandy interbeds.

The various types of SSD structures present are described first followed by details of the lateral and vertical distribution according to the ideas of Rodriguez Pascua (1997) and Rodríguez-Pascua et al. (2000), as these authors discussed and arranged Late Miocene Prebetic lacustrine deposits in order of decreasing seismic magnitude. Many of the observed structures fit into their scheme.

\section{Syndepositional faulting and fault-grading}

Small-scale faulting is common within the laminated and thin-bedded LM intervals. Most of this is a post-depositional feature, but several examples prove that syndepositional faulting also occurred. The simplest variety (Fig. 7A) shows the break up of the laminites, followed by infilling of the deformed relief. This break-up caused differential tilting of the broken beds to form a faulted anticline with an intensely brittle deformed central part. A second example (present in LLM locality B1; Figs 2 and 7B,C) shows a thin sandstone bed pinching-out over a short distance, consisting of a mixture of liquefied sand and irregularly shaped marlstone fragments (pseudonodules). This bed is crossed by two sub-parallel normal faults which caused a slight dip rotation

Fig. 7. Deformation features in offshore, finely bedded Lago Mare deposits. (A) Simple small-scale faulting with subsequent infilling of the deformed bottom sediment by settling of fines. (B) Overview of so-called large Lago Mare outcrop (section C, interval 3; fine-grained whitish Lago Mare interval is $7 \mathrm{~m}$ thick here), exposing panels (C; see arrow for location) and (D) at the upward coarsening top and transition to overlying coarse clastics. (C) Wedgeshaped, slightly faulted sandstone bed, indicated by interrupted lines, consisting of a mixture of liquefied sand and highly irregular marlstone fragments filling-out a relief caused by a slight $\left(\sim 6^{\circ}\right)$ rotation of a faulted bottom segment. Syndepositional tilting is indicated by the difference in dip between the underlying and overlying beds in the middle block indicated with ' $\mathrm{X}$ '. (D) Fissure-shaped sand dykes, both vertical and oblique, forming downward-pointing coarse sandy injections in the laminitic strata. The levels indicated 'a' to 'e' all are terminations of fissures. Of these, level 'e', at the sandier transition to the overlying coarse clastics, clearly is the termination of the largest sand dykes, which locally liquefied the surrounding sandstone beds. Box shows position of Fig. 8C. The arrow at level 'd' indicates a siliceous concretion. 


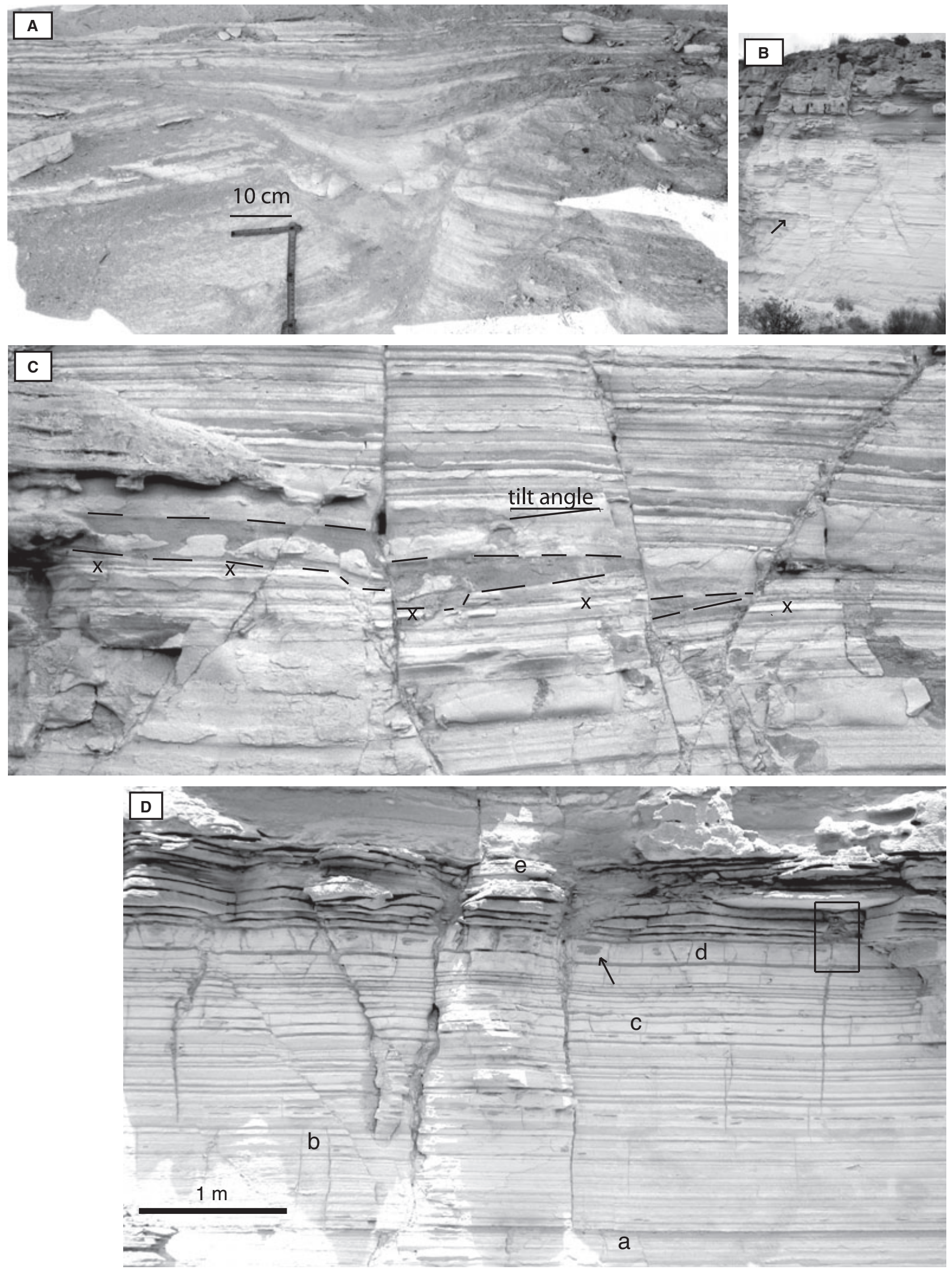


$\left(\sim 6^{\circ}\right)$. Syndepositional tilting of this segment is indicated by the difference in dip between the underlying and overlying beds. The overlying sand fills in the triangular space created by the rotated fault block, thus smoothing the newly created sea floor irregularity.

A third variety shows small-scale break up of varved sediment in association with partial liquefaction of the sand fraction that now fills the voids between the broken strata. The broken beds are covered by a graded turbidite bed with a lower erosional surface that truncates the pre-existing positive relief. This latter variety forms a transitional stage with the sand dykes discussed below (Fig. 8D). The faults and joints are roughly orientated NE-SW and NW-SE.

\section{Interpretation}

Small-scale faulting coupled with the filling-in of newly created relief points to syndepositional activity on the basin floor. Both differential compaction and tectonics may cause small-scale faults. In the first example described (Fig. 7A), no liquefaction indicating a shock has taken place. In the case of faulting by compaction the deformation would be normal, rather than the combination of compression and extension seen here. Given that strike-slip fault activity was common in the study area during the Late Messinian, a seismic origin is more probable. In the second example (Fig. 7C), the tilted fault segment has been reactivated later as shown by the normal faults that now continue further up; this may also happen with compaction faults. However, the combination of this deformation with sand-carrying pseudonodules filling up the newly created relief indicates liquefied flow, suggesting triggering by severe shocks. This pattern resembles fault-grading in the sense originally defined by Seilacher (1969), although the basal broken and fault segmented zone is less well-developed. Fault-grading sensu Seilacher (1969) is a deformational structure that grades from a step-faulted bottom part, via a stratal fragment-rich rubble zone into completely liquefied sediment at the top. Such structures are widely accepted as indicators of seismic activity. The present authors agree with Plaziat \& Ahmamou (1998) that this type of fault-graded bed is induced by intraformational dislocations. Variety 3 also resembles fault grading, but here liquefied sand-filled voids opened by hydraulic fracturing between the broken marlstone. Because a graded bed with an erosional base fills the relief, seismicity may also have triggered a turbidity current. The fault grading features discussed here correlate laterally with both mixed layers and sand dykes discussed below.

\section{Sand dykes}

These structures consist of generally vertical to obliquely orientated, coarse sand injections crosscutting laminited strata. The sand dykes may exceed $1 \mathrm{~m}$ in length (Fig. 7D) and are up to $3 \mathrm{~cm}$ wide, varying in shape from slightly anastomosing to almost rectilinear; they extend from the upper, confining bed downward where they end in fissures. These structures are best developed between Los Feos and Barranco Castellones (sections A to D) in the upper part of the LLM interval (interval 3 of Fig. 4). The upper part of this level is characterized by the rapid increase of sandy intercalations in the chalky marls that eventually pass into the overlying continental coarse clastics caused due to upward shoaling.

There are differences in the style and size of the sand dykes. At Los Feos section A (Fig. 4) the smaller and more irregular dykes (Fig. 8B) tend to follow a conjugate pattern orientated around $50^{\circ} \mathrm{N}$ and $140^{\circ} \mathrm{N}$; they are cut by a thin-graded turbidite bed with a sharp, scoured base. The sand filling these fissures, however, differs from this turbidite bed in having a coarser grain-size, which indicates a different provenance. Either the source sand was eroded prior to deposition of the turbidite, or the fissure filling is what remains of a completely liquefied sand. Groove and flute casts in this turbidite bed indicate southward transport $\left(170^{\circ} \mathrm{S} ; 13\right.$ readings), while Tc intervals of very thin distal turbidites at this level indicate similar south to SSE transport directions. The first medium-bedded sandstone, a few decimetres higher up, shows HCS, thus indicating rapid upward shallowing to near-shore sands that are overlain continental coarse clastics.

\footnotetext{
Fig. 8. (A) Detail of another sand-filled fissure in the same LLM outcrop as Fig. 7D, level 'e', showing dish-shaped liquefaction at termination. (B) Detail of the upper termination of a composite fissure, Los Feos locality, section A (pencil for scale is $15 \mathrm{~cm}$ long). (C) Another example of liquefaction structures in LLM outcrop. (D) Small, somewhat anastomosing fissures cut by a thin graded turbidite, showing strong erosion at the base (Los Feos). (E) Two closely spaced 'mixed layers' generated as a mixture of hydroplastic deformed laminites (scale is $12 \mathrm{~cm}$ ). (F) Transition from graded, undeformed to graded matrix-supported top in a 'mixed layer', exposed $0.5 \mathrm{~km}$ east from Los Feos, LLM interval 4.
} 

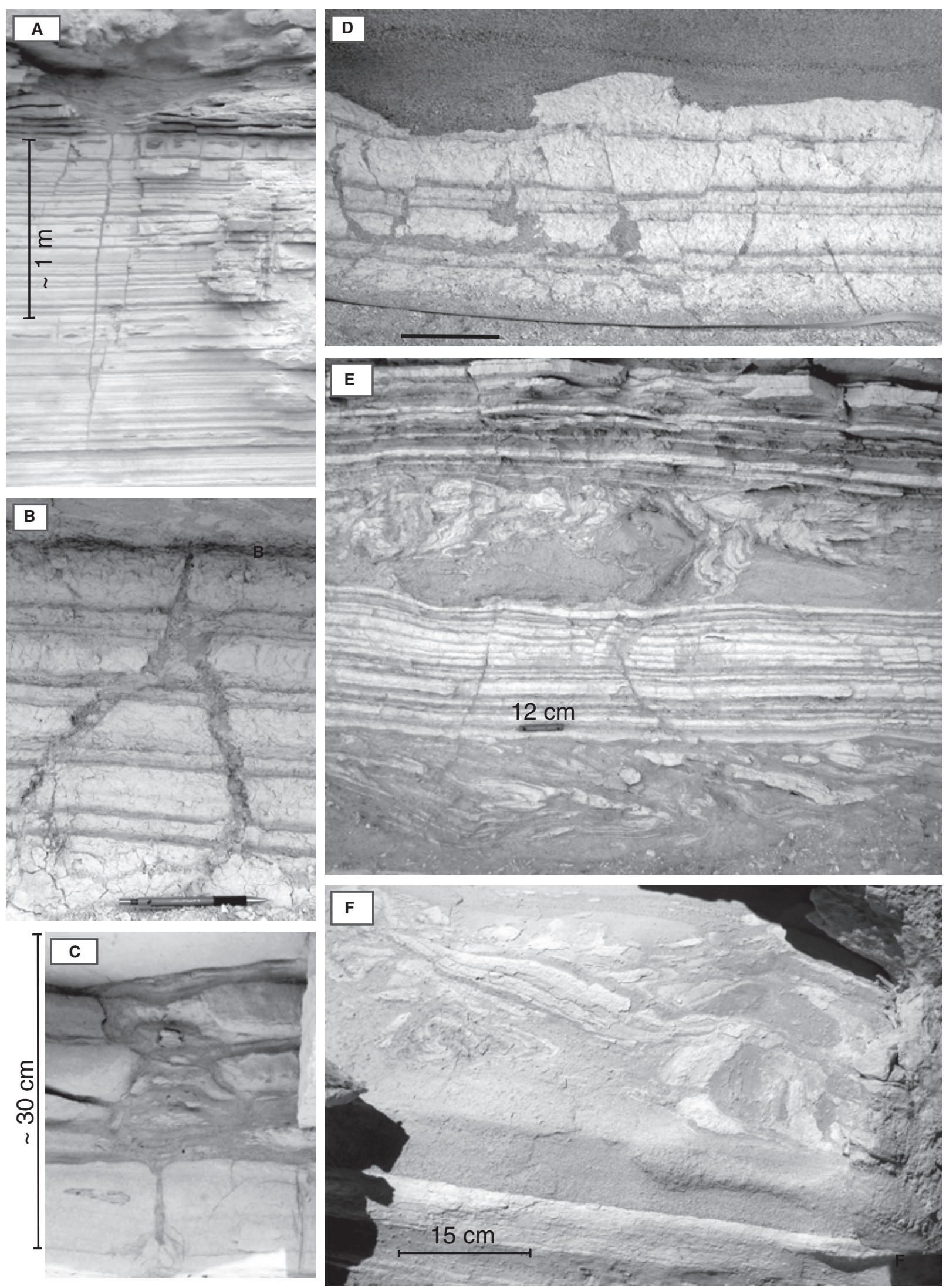
The best outcrop for these structures (the LLM outcrop, section C; Fig. 7B and D) includes several levels with sand dykes. The largest dykes are present at the top, where they terminate upwards in graded sands. Distinct liquefaction structures can be seen at their upward termination (Fig. 8A and C). The shape of these liquefied bodies varies from wide, conical, with the apex at the termination of the fissure/dyke, to a narrower conical/cylindrical zone. Although these uppermost sand dykes are the clearest examples in this outcrop, at least four additional, minor fissured horizons can be distinguished (levels a to $\mathrm{d}$ in Fig. 7D).

\section{Interpretation}

The coarser grain-size and colour of the sand indicates that the sand filling the dykes cannot have been provided by upward flow from the lower finer-grained laminitic sandy intervals. Thus, the dykes must have been filled from above and perhaps sideways by locally fluidized sand (such as shown in Fig. 7C); this indicates a coseismic shockwave resulting in the formation of tension gashes (cracks). Expulsion of pore water to the surface took place and was able to liquefy sands at the top, as seen in the LLM outcrop. This sand, together with liquefied sands from lower beds subsequently filled the remaining space in a downward direction. The termination of many dykes at the level of a graded sandstone interbed suggests a relationship between seismic shocks and the triggering of a turbidite. The occurrence of several levels with sand dykes of different dimensions not only indicates the recurrent character of seismicity but also a variety in intensity of shaking.

\section{Mixed layers}

The term 'mixed layer' (Marco \& Agnon, 1995) has been introduced for chaotic beds typically show- ing an upward transition from folded sediment, via a disrupted and fragment-supported texture, to a matrix-supported texture at the top; they have been shown to relate in a lateral sense to fault-slip planes caused by seismic shocks of moderate to high magnitude. Rodríguez-Pascua et al. (2000) distinguish mixing bodies that lack the fluidized upper unit probably because the earthquake magnitude did not exceed the force needed to fluidize the laminites. Many palaeoseismite studies report similar features, variably describing them as 'ball-and-pillow structures' and 'hydroplastic deformation' (Hempton \& Dewey, 1983; Davenport \& Ringrose, 1987; Plaziat et al., 1990; Mohindra \& Bagati, 1996; Bowman et al., 2004).

Both types can be observed, especially within the LLM interval (3) from Los Feos (section A) to Gafares (east of Los Castellones, section D). Here two examples are shown (Fig. 8E and F). In the first case (Fig. 8E), two closely spaced layers form mixtures of hydroplastically deformed laminites. In the second case (Fig. 8F), there is a transition to a graded matrix-supported top. This latter example, which occurs $0.5 \mathrm{~km}$ east of LLM outcrop B (interval 3), is considered a lateral variety of the faulted and rotated sandstone bed there (Fig. 7C). From Gafares further east this level is present as a much thicker $(>100 \mathrm{~cm})$, and therefore laterally traceable, 'slump bed' (Fig. 4).

\section{Slumping and sliding of sandstone beds}

Thick, slumped sandstone beds are rare. In section B, in the Barranco Gordo (Figs 2 and 4), the LM interval attributed to sequence 3 includes an up to $2 \mathrm{~m}$ thick sandstone bed which passes laterally into broken and slumped elements. The bed essentially consists of a basal, $50 \mathrm{~cm}$ thick, crudely graded pebbly sandstone, followed by well-sorted, irregularly parallel laminated sandstone, containing isolated pebbles and boulders in its upper part (Fig. 9A). The graded and

\footnotetext{
Fig. 9. Some examples of 'slumped' sandstone beds. (A) Barranco Gordo (section B), an up to $2 \mathrm{~m}$ thick slumped sandstone layer containing, in ascending stratigraphic order: basal, crudely graded pebbly sandstone followed by laminated sandstone with isolated pebbles and boulders towards the scooped top. Note two fragmented zones with partial liquefaction (arrows), indicating where upward fluid escape has taken place. At the top, near the hammer for scale (28 cm long), Lago Mare beds can be seen to fill in the depression. The boulders to the right of the hammer have probably fallen from the overlying coarse-clastic beds. (B) Tightly crumpled and folded LM laminites at the frontal (southern) side of an isolated sandstone body occurring $50 \mathrm{~m}$ laterally from the sandstone shown in Fig. 9A. The orientation of the axial plane of folds indicates southward sliding, also being the direction in which the sandy beds are pinching out. (C) Convolute bedding fine-grained and laminated gypsarenites, $5 \mathrm{~m}$ below (stratigraphically) the former layer. These beds belong to an interval rich in reworked gypsum, deposited as graded debris lobes. (D) Loosely deformed laminated gypsarenites corresponding laterally to the tight convolutions shown in Fig. 9C. (E) Flame structures with fine-grained, silty laminae protruding upward into a coarse-sandy gypsarenite, and showing a vergence perpendicular to the palaeocurrent direction (diameter of coin for scale is $2 \mathrm{~cm}$ ).
} 

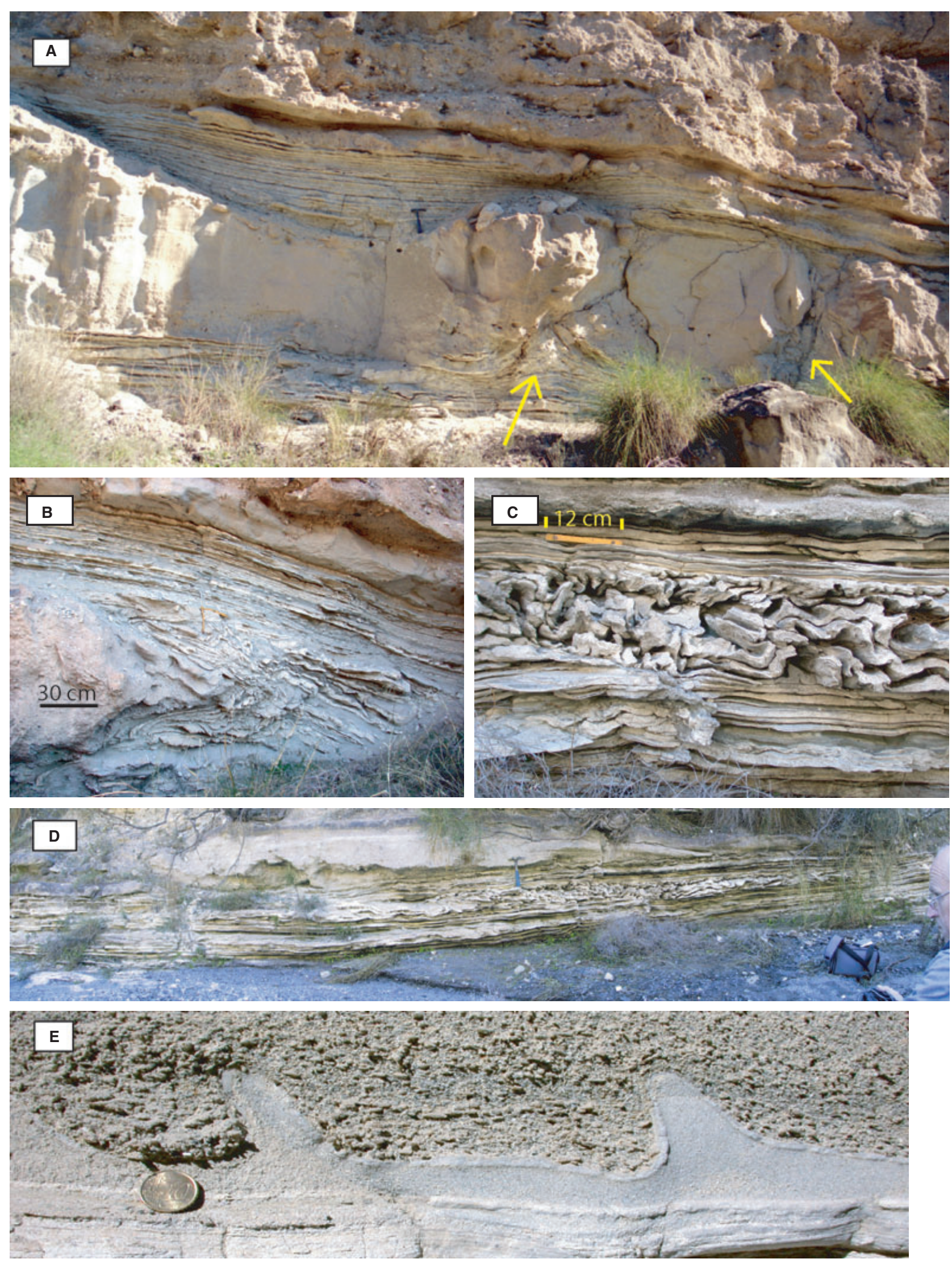
laminated internal structure suggests deposition from a sand-rich mass-flow, although the gently undulating irregular parallel lamination higher up suggests influence by breaking waves in the swash zone; however, this is unlikely considering its position within thin-bedded varved offshore laminites. The bed abruptly breaks up southward, where several up to $3 \mathrm{~m}$ across isolated sandstone bodies can still be observed in the river bed $50 \mathrm{~m}$ away from this outcrop. These bodies are associated with tightly crumpled and folded LM laminites (Fig. 9B). The west to east orientation of the axial plane of folds indicates southward sliding. Just before the point of breakage, the sandstone shows a scooped upper surface (Fig. 9A) on which there are isolated cobbles. This surface, plus the presence of laminites filling in relief suggests that local scouring with the formation of a lag deposit has taken place prior to deposition of the laminites. Evidence for erosion is not found laterally. The lowermost bed filling in the scour is an up to $20 \mathrm{~cm}$ thick mudstone including sandstone patches.

The laminites underlying this sandstone are almost undisturbed except near and in front of the point of breakage. Near this point, upward fluid escape has taken place, as illustrated by two fragmented zones with partial liquefaction (Fig. 9A, arrows).

\section{Interpretation}

This slump bed in Barranco Gordo is in a more proximal position with regard to coeval deposits exposed further south and east and, therefore, closer to the Sierra Cabrera which underwent differential uplift during this period. The position of this anomalously thick LM sandstone intercalation, its graded basal portion with pebbles floating in a sandy matrix and vague horizontal lamination suggest that this bed originated from a mass flow event, carrying remobilized sand, gravel and boulders into the basin. The absence of repeated positive grading or amalgamation of beds points to a single event. Because of the abnormal thickness of this bed, in comparison with the normal thin-bedded to medium-bedded character of the LM sandstone interbeds, it has the aspect of a mega bed. Such mega beds may well be triggered by seismicity, but this can rarely be proven (Ricci Lucchi, 1995). The emplaced load caused gravitational instability and break up, with local upward fluid escape from the underlying mud. Although the described feature is a largely gravity-driven deformation, a relationship with seismicity is consistent with its stratigraphic position as other types of SSD at this level can be interpreted as seismically triggered.

\section{Convolute bedding, pillar and flame structures}

Convolute bedding is almost exclusively confined to the thin-bedded, fine-grained and graded detrital gypsum intervals occurring in the basal part of the formation close to Los Feos (sections A, B and C; Fig. 2). These beds, which are associated with the sand-rich cycles, become thicker and coarsergrained when traced eastward to Gafares and decrease in grain-size and thickness further east (sections $\mathrm{E}$ and $\mathrm{F}$ ). This effect can be interpreted as the transverse section of a relatively flat, lobate morphology, with a source area to the north. It is suggested here that such a lobe, made up of graded and reworked gypsum-rich debris, forms the distal parts of small turbidite-like depositional lobes (Fig. 9C). Although the local extent of the most intense convolutions seems restricted (Fig. 9D), the convolutions were observed in several outcrops at the same stratigraphic level. This level corresponds with the basal manganese hydroxide enriched sand-rich and gypsareniterich level forming the boundary bed with the underlying Yesares Formation (Fig. 4). Where laminated convolute gypsarenite and thin sandmarl alternations occur together, the latter tend to develop flame structures (Figs 9E and 10B).

Simple flame structures, varying in size between 1 and $10 \mathrm{~cm}$, consist of fine-grained, usually silty and sandy laminae protruding upward into coarser sands. The morphology of these structures conforms to the so-called regular small-scale flame structures as described by Brodzikowsky \& Haluszczak (1987) from the Quaternary of Poland; they often show a vergence opposite to the palaeocurrent direction (Fig. 10B). Apart from their presence in the basal part of the formation (Fig. 9E), these structures have also been observed in the upper part of the underlying Yesares Formation, again in intervals rich in reworked gypsum.

The structures observed in section D (Fig. 2), at the equivalent level of the manganese boundary bed deserve special attention. This $2 \mathrm{~m}$ thick, sand-rich interval which underlies a thick graded and undeformed gypsarenite bed shows a repetitive association of pillars and flames in the thin muddy interbeds (Fig. 10B); these are situated directly above irregularly stratified, medium to coarse-grained sands. These sands comprise several irregularly dispersed, wedge-shaped levels containing a mixture of elongated, partly hydro- 

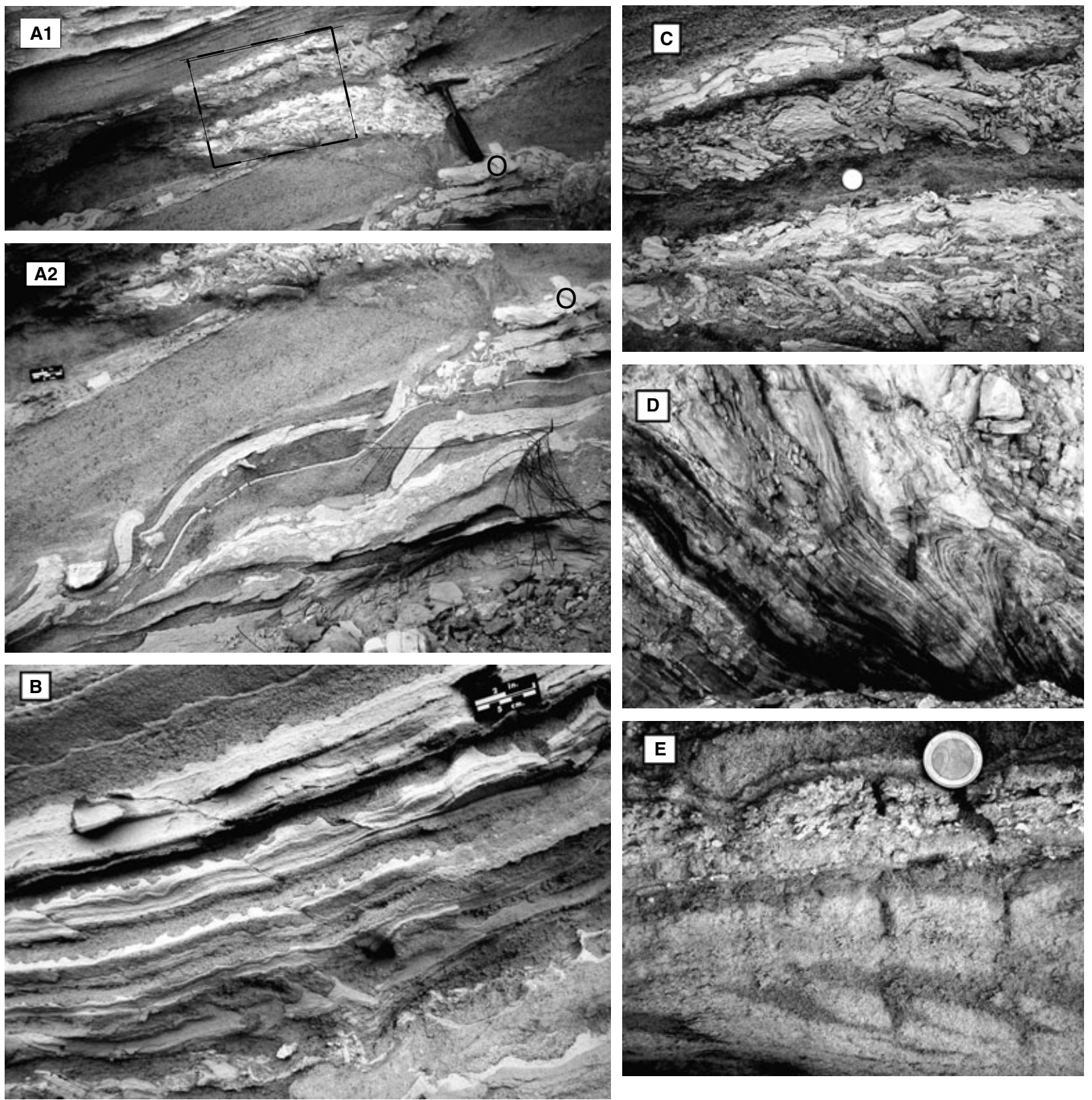

Fig. 10. (A) to (C) Repetitive association of pillar and flame structures, together with thin hydroplastically deformed and liquefied beds, as observed in section D, Castellones, at the basal Feos Mn-bed. Pictures (A1) and (A2) partly overlap, but with different scales, circle below hammer corresponds to circle in (A2). Box in (A1) gives outline of (C). Picture (B) is positioned just above (A1). (D) Hydroplastically formed slump folds in the same sandy laminated Mn-bed as the previous photos, but $1 \mathrm{~km}$ further east at Gafares. (E) Small-scale compressional soft-sediment deformation structures as observed in a sand-silt interval within the continental part of Feos cycle 3, section C (at $35 \mathrm{~m}$ level). Hammer for scale in (A1) and (D) is $28 \mathrm{~cm}$ long. Coin for scale in (C) and (E) has a $2.5 \mathrm{~cm}$ diameter.

plastically deformed marl fragments. Pillar structures of fluidized sand connect these wedges to a more continuous level with complex flame structures (Fig. 10A and C). Many of the marl fragments in the wedges are imbricated, suggesting SE-directed compression or flow (Fig. 10C). The more continuous interval, shown in Fig. 10(A2), most closely resembles the middle portion of a typical mixed layer as, for example, figured by Davenport \& Ringrose (1987), Marco \& Agnon (1995), or Rodríguez-Pascua et al. (2000) and the water-escape features with complex flame structures shown by Mohindra \& Bagati (1996). Further to the east, at Gafares and beyond, this level develops into hydroplastically formed slump folds (Fig. 10D). 


\section{Interpretation}

The presence of intervals with deformed, but imbricated, marl clasts points to directional deformation, such as shear stress exerted by a gravitational force, or sub-aqueous currents. The irregular and rather chaotic wedges (Fig. 10C) make an origin by sub-aqueous currents less probable, as does the presence of fluid-escape pillars from one level to another. It is, therefore, assumed that this association is the result of a downslope gravitational body force as, for example, triggered by seismicity. The upward decrease in the extent of deformation in this outcrop, culminating in small-scale flame structures, suggests an overall decreasing intensity of water escape and associated deformation. Given the lateral continuity of SSD at this stratigraphic level, one of the diagnostic factors of seismic triggering (Sims, 1975), seismicity, is identified as the most probable. It remains uncertain whether the whole association is the result of a single event or of repeated shocks.

Because of their laterally traceable position within, or close to the manganese boundary bed, it is possible to constrain lateral and vertical patterns in the deformation. Convolute lamination and flame structures are best developed in the thin-bedded (gyps)arenite-marl alternations. Given the more hydroplastically deformed marls in the thicker sands and larger-scale deformations further east in the study area, it is probable that systematic changes in grain-size and bed thickness are an additional control on the character of the deformation.

\section{Soft-sediment deformation in internal continental Feos cycles}

If seismic shocks occurred randomly in space during the Late Messinan, the continental intervals deposited further basin inward during episodes of drawdown of the LM waters might also show evidence for SSD. Because these intervals are generally less well-exposed or accessible, the focus was on the study of the LM intervals. Although fluid-escape structures and small-scale deformational structures indeed occur (Fig. 10E), they are not of the scale and density seen in the basin margin deposits. Two reasons for their poor representation in this more central part of the basin could be: (i) a relatively low position of the water table during the terrestrial parts of the cycles, in contrast to the coarse marginal clastics described in the previous section that were deposited in front of and above the basin- ward-dipping clinoforms of the older Messinian reef margin complex where phreatic waters could infiltrate; and (ii) a more distal position to active fault planes together with a lower susceptibility to liquefaction compared with the LM deposits because of the coarser-grained fabrics.

With regard to the first possibility, it should be kept in mind that these reef clinoforms were already being uplifted and exposed during the continental Feos episodes (Fortuin \& Krijgsman, 2003). Gypsum dissolution in this NW part of the study area indicates the relative importance of groundwater. As pointed out by $\mathrm{Lu}$ (2006) the radiogenic Sr content in Feos gypsum interbeds implies that Feos brines had a significant contribution of freshwater. In general, groundwater levels may be expected to be higher more basin inwards but, in the particular setting of basinward-dipping clinoforms pinching-out in less permeable, marl-rich strata, a relatively high groundwater level may well have existed at the former reef front during deposition of these marginal coarse clastics.

\section{INFERRED SEISMIC ACTIVITY, LATERAL AND VERTICAL TRENDS}

Many of the SSD structures described and figured above satisfy the criteria given by Sims (1975) for structures formed by seismic events, such as: (i) position of the study area within a seismically active region; (ii) presence of potentially liquefiable sediments; (iii) similarity to structures produced experimentally; (iv) internal structures within the deformed zones that suggest liquefaction; (v) deformation structures confined to single stratigraphic horizons; (vi) structures that can be correlated over larger distances within the sedimentary basin; and (vii) the lack of detectable influence of slopes, or slope failures. Moreover, these features are in many ways comparable, if not similar, to structures interpreted by many researchers as caused by seismicity. At least part of the structures described here, however, could have been caused by non-seismic factors, such as sediment loading, or slumping and sliding because of instable slope conditions. On the other hand, the study area conforms to the criteria given by Ricci Lucchi (1995) as providing appropriate conditions for the preservation of seismites, such as location in a seismically active area, variable sediment input to produce heterolithic deposits and absence of bioturbation. It is assumed here that the repeated occurrence of 
deformational horizons, the variations in intensity of the deformation, and their lateral continuity together identify seismicity as the most plausible factor causing sediment destabilization.

Previous studies have already established the fundamental influence of active tectonics on shaping the Nijar and adjoining basins during this latest Miocene interval (Montenat et al., 1987a,b, Coppier et al., 1990; Stapel et al., 1996; Huibregtse et al., 1998; Montenat \& Ott d'Estevou, 1999; Jonk \& Biermann, 2002; de Larouzière et al., 1988; Fortuin \& Krijgsman, 2003; Martinez-Diaz \& Hernandez-Enrile, 2004). A link between most of the sediment deformation features discussed here and seismic activity therefore seems plausible. In particular, the indications for liquefaction close to fault intersections, both in the continental coarse clastic marginal facies and in the offshore LM facies, are forceful. However, evidence for turbidity currents means that the possible role of a basinward slope for some of the deformation types observed cannot entirely be ruled out. The Feos clastics were especially transported to more distal areas of the basin by ongoing uplift of the surrounding sierras, mainly Sierra Cabrera at the northern margin of the basin. The fact, however, that SSD is not related to locations containing the thickest turbidites, suggests that slope instability was not a factor of crucial importance. Moreover, the moderate sediment accumulation rates exclude the role of sediment instability caused by rapid overloading. With an estimated duration of the Feos depositional episode ( $\sim 200 \mathrm{ka}$, Fortuin \& Krijgsman, 2003) and a thickness locally just exceeding $100 \mathrm{~m}$, an average accumulation rate of around $0.5 \mathrm{~mm}$ year $^{-1}$ is deduced. This rate is not particularly high.

The possible influence of storm-wave action must also be considered. Storm-wave action has been invoked by Alfaro et al. (2002) to cause SSD in coeval deposits in the Bajo Segura Basin further to the north (a conclusion refuted by Montenat et al., 2007). Wave activity most probably took place in the Nijar Basin at the upward shallowing from LM to the continental intervals. Small-scale HCS, indicative of storm-wave action, has been observed in the tops of two LM intervals (Fig. 4, sections A to D). The liquefaction-related structures discussed and figured here, however, are not associated with these beds. In contrast, they occur lower in the succession where the sandy interbeds commonly show grading and currentripple cross-bedding (Bouma Ta-c intervals). Although flame structures associated with HCS bedding have been observed in the lower part of section D, it is concluded that seismic shocks remain the most plausible triggers of at least the majority of the SSD features in the study area.

Lateral changes in the style of SSD structures can best be studied in the dark coloured manganese boundary bed and within the LLM unit (cycle 3, Fig. 4). In relation to this latter unit, evidence for at least four different SSD levels can be observed in the best outcrop (Fig. 7B); of these, two are most widespread. The lower level, positioned close to the middle of the unit is the thickest, up to $1.4 \mathrm{~m}$, in Barranco Gafares, showing slump folds oriented to $80^{\circ}$ to $130^{\circ} \mathrm{SE}$. In this latter outcrop, the upper deformed bed of the mixed layer type is correlated (on the base of its similar position within the sequence) with the sand-filled fissures/dykes observed in the area between sections A and C. The thick, slumped sand mass of section B (Fig. 9A), which is located in the most proximal position considering the overall NW-SE transport, could also belong to this level. As the overlying continental coarse clastics slightly truncate the LLM interval northwards, an alternative option is correlation with the broken beds halfway along this interval in section C (Fig. 7C). Despite these uncertainties, lateral intergradation of several styles of deformation is evident. In these cases the thicker, more eastward sections include the more laterally displaced sediments (slumps), suggesting more important slope-driven deformation.

As already discussed in the section on pillar and flame structures, comparable lateral changes have been observed in the basal Mn-hydroxideenriched boundary interval. This marker level is up to $3 \mathrm{~m}$ thick and includes a horizontally laminated sandstone bed with loading and fluid-escape structures, such as near Gafares, where this bed is $60 \mathrm{~cm}$ thick. Eastward, in the Collado del Manco, this deformed bed is most pronounced (Fig. 10D), whereas flame and associated hydroplastic structures occur in section D (Los Castellones).

Overall deformation structures are more common in the basal half of the Feos Formation, especially in the well-exposed sections between Feos and Gafares, than further east (Gafares to Collado del Manco). In these latter and more distal 'deeper' successions the most important deformational levels can still be recognized and used as marker beds. The more common presence of SSD structures in the lower half of the formation, although somewhat biased because of the more favourable exposure conditions, suggests a decreasing intensity of the seismicity with time. With regard to the regional context, seismicity 
has already been shown to have destabilized sediments of the Sorbas Member (Roep et al., 1998) in the SE Sorbas Basin (Fig. 3), which is the time interval just preceding the Feos sedimentation. Taken together with the lower Feos Formation, this is the time interval during which the Sierra Cabrera, presently separating the study area from the SE Sorbas Basin, started to uplift (Fortuin \& Krijgsman, 2003). With the eastward decrease in the relative proportion of soft-sediment deformation structures in the Feos sedimentary record, it seems that the seismic activity was predominantly associated with tectonic movements in the northwestern segment of Sierra Cabrera. The easternmost sections, however, are in a closer position to the major sinistral Carboneras strike-slip fault zone. Folding is tighter towards this fault and the boundary between the terrestrial-lacustrine Feos sediments and the overlying open marine Pliocene changes from conformable near Gafares to unconformable (angular unconformity) towards this fault zone. An explanation could be that in the NW part differential movements between Sierra Alhamilla and the western sector of Sierra Cabrera caused increased seismicity. Moreover, a Messinian gypsum-rich olistostrome bordering the southern boundary fault of the Sierra Cabrera east of Polopos (Fig. 2) attests to considerable tectonic activity in the NW part of the study area. Apart from possible lateral differences in seismicity, lithological differences may have played a role. The heterolithic character of the lower LM intervals in particular, as expressed by the often thinbedded sand-marl couplets, is more prominent in the area between Los Feos and Gafares than further eastward. Modelling experiments (Moretti et al., 1999) show that pillar structures form as a result of liquefaction and fluidization in graded beds where each bed is followed upwards by a thin layer of clay. Indeed, these structures are observed (Fig. 8) where this type of bedding is best developed.

\section{FREQUENCY AND MAGNITUDE OF PALAEOSEISMIC EVENTS BASED ON SEDIMENTARY EVIDENCE}

A key aspect of the Feos Formation is the cyclicity shown by the repeated alternation of coarser clastic, often continental, intervals and LM facies (Fig. 4); this has been interpreted as a result of a strongly fluctuating water budget in the (almost) totally restricted Mediterranean (Fortuin
\& Krijgsman, 2003; Bassetti et al., 2006). Periods of relative drought caused subsequent lowstand of Mediterranean waters, providing either 'lacustrine' gypsarenitic, or fully continental deposits in the Nijar Basin. During more humid conditions with increased run-off, relatively high water levels were established in the basin. Various studies have shown that such climatic changes relate to orbital forcing. In particular, precession is well-known to have controlled the sedimentary record of the Mediterranean basins during both the Late Miocene and Early Pliocene (Griffin, 2002; Sierro et al., 2003; van Assen et al., 2006) and was demonstrated for the Messinian successions in the adjacent Sorbas Basin (Krijgsman et al., 2001). This latter record of eight cycles for the interval covering the LM episode agrees well with the seven to eight LM cycles present in the study area (Fig. 4; Fortuin \& Krijgsman, 2003). As recent modelling results (Meijer \& Krijgsman, 2005) show that complete desiccation and refilling of the Messinian Mediterranean can easily occur within one precession cycle, there is no reason to assume that the Feos cycles form an exception to the overall precession-dominated Mediterranean climatic cycles. Thus, the average duration of the Feos cycles is estimated around $22 \mathrm{kyr}$; this makes it possible to estimate the recurrence interval of seismite-triggering earthquakes. Assuming the LLM interval approximately represents half a precession cycle, it has been deposited somewhere between 8 and 14 kyr. With at least four seismite levels observed in the best outcrop, a recurrence interval between 2 and $3.5 \mathrm{kyr}$ is implied. Although this is a rough approximation, especially given the biased record of seismites, it is interesting to note that this agrees well with the recurrence interval of 2 to $3 \mathrm{kyr}$ for major earthquakes in the Betic domain (Reicherter et al., 2003). Liquefaction hazard studies for the convergent plate tectonic setting of Japan (Kanaori et al., 1993) indicate that active seismic periods, resulting in the formation of sand-filled dykes, occurred with an interval of approximately $1 \mathrm{kyr}$. These authors also concluded that liquefaction and flowage mainly occurs within $15 \mathrm{~km}$ wide zones along tectonic faults, a scale consistent with the Nijar examples.

The magnitudes of the earthquakes causing the Nijar seismites can be approximated using engineering geological data and comparison with analogues, such as provided by Rodríguez-Pascua et al. (2000). These authors presented an overview of several seismite types in lacustrine formations of Prebetic basins in relation to earth- 
quake magnitudes. Although the types of gravel liquefaction in the old railway outcrop ( $\mathrm{R}$ in Fig. 2) are not reported, liquefied and intruded gravels score high on their list. This observation is in agreement with Obermeier (1996) and Obermeier et al. (2005), who state that the threshold magnitude to induce liquefaction in the most susceptible gravel is around $M=7$ to $7 \cdot 5$. Because this location is only $3 \mathrm{~km}$ from the northern major Alpujarras fault zone (Fig. 2) and very close to the fault bounding the south of the Sierra Cabrera, it is possible that very large earthquakes $(M>7)$ occurred during the Late Messinian.

The question then arises as to whether seismicity played a more important role during the Late Messinian Feos episode of drastic facies changes, or whether it was also important just before or after the salinity crisis, when the deposits formed had a lower potential to record seismites? The aberrant basinal and sea-level conditions governing the terminal Messinan Mediterranean and the resulting (hydro)isostatic unbalance probably would have favoured greater susceptibility to SSD. As pointed out by DeCelles \& Cavazza (1995), Late Messinian sea-level changes may well have contributed to increased tectonics. On the other hand, the field data do not provide compelling evidence to conclude stronger seismicity than at present. Thus, for the time being, it is concluded that the Feos Formation is not only a key succession for the reconstruction of the terminal Messinian history of the Mediterranean, but that it also is relevant for palaeoseismicity.

\section{CONCLUSIONS}

A variety of soft-sediment deformation (SSD) features occurs within the Late Messinian deposits of the Nijar Basin, an episode during which the Mediterranean-wide Lago Mare (LM) facies was deposited. Most of these SSD structures are interpreted as seismites. The cyclic pattern of alternating 'lacustrine' LM and continental alluvial facies in the Nijar Basin was formed under a regime of orbitally forced, most probably precession related, climate-driven cycles of strongly fluctuating high and low standing base levels. With proven tectonic control, for example, by uplift and erosion of the nearby basin margin and activity on the Carboneras strike-slip fault, the basin offers an outstanding opportunity to study seismites in a stratigraphic and lateral context. Minor strike-slip faults cross the study area and their activity also visibly played a role.
The strongest seismic shocks with a magnitude $M>7$ were capable of inducing gravel liquefaction. Such liquefactions have only been observed in the NW part of the study area, close to major faults associated with uplift of Sierras Alhamilla and Cabrera.

In the LM facies, seismites involving liquefaction with little to moderate sediment transport, such as resulting from fissure filling and fault grading, pass basinward and downslope into more 'classical' slump beds. The occurrence of up to four or five levels with sand dykes, all of different scales, within a single LM cycle indicates not only the recurrent character of seismicity, but also a varying intensity of ground shaking. The recurrence interval has been estimated to be in the order of 2 to $3.5 \mathrm{kyr}$. There is no compelling evidence to conclude stronger regional seismicity than that observed today, apart from the possibility of motions driven by hydro-isostatic rebound related to the repeated, climate and precessionforced rising and falling of the Lago Mare water level.

\section{ACKNOWLEDGEMENTS}

This paper is a contribution to the research programme of NSG, the Dutch Research School for Sedimentary Geology. CJD's research was facilitated by Project BTE 2004-01866 and CGL2005-01336/BTE. Discussions with Wout Krijgsman and Adrian Immenhauser were highly appreciated. This paper benefitted from the constructive reviews by an anonymous colleague, Klaus Reicherter and especially Peter Haughton.

\section{REFERENCES}

Aguirre, J. and Sánchez-Almazo, I.M. (2004) The Messinian post-evaporitic deposits of the Gafares area (Almeria-Nijar basin, SE Spain). A new view of the "Lago-Mare" facies. Sed. Geol., 168, 71-95.

Alfaro, P., Estévez, A., Moretti, M. and Soria, J.M. (1999) Structures sédimentaires de déformation interprétées comme séismites dans le Quaternaire du bassin du Bas Segura (Cordillère bétique orientale). C.R. Acad. Sci. Paris, 328, 1722

Alfaro, P., Delgado, J., Estévez, A., Molina, J.M., Moretti, M. and Soria, J.M. (2002) Liquefaction and fluidization structures in Messinian storm deposits (Bajo Segura Basin, Betic Cordillera, southern Spain). Int. J. Earth Sci. 91, 505-513.

Ambraseys, N. (1988) Engineering seismology. Earthquake Eng. Struct. Dyn. 17, 1-105.

Assen, E. van, Kuiper, K.F., Barhoun, N., Krijgsman, W. and Sierro, F. (2006) Messinian astrochronology of the Melilla 
Basin: Stepwise restriction of the Mediterranean-Atlantic connection through Morocco. Palaeogeogr. Palaeoclimatol. Palaeoecol., 238, 15-31.

Bassetti, M.A., Miculan, P. and Sierro, F.J. (2006) Evolution of depositional environments after the end of Messinian Salinity Crisis in Nijar basin (SE Betic Cordillera). Sed. Geol. 188-189, 279-295.

Booth-Rea, G., Azañón, J.M., Garcia-Dueñas, V. and Augier, R. (2003) Uppermost Tortonian to Quaternary depocentre migration related with segmentation of the strike-slip Palomares Fault zone, Vera Basin, SE Spain. C.R. Geosci. 335, 751-756.

Bowman, D., Korjenkov, A. and Porat, N. (2004) Late Pleistocene seismites from Lake Issyk-Kul, the Tien Shan range, Kyrghyzstan. Sed. Geol., 163, 211-228.

Braga, J.C., Martin, J.M. and Quesada, C. (2003) Patterns and rates of late Neogene-Recent uplift of the Betic Cordillera, SE Spain. Geomorphology, 50, 3-26.

Brodzikowsky, K. and Haluszczak, A. (1987) Flame structures and associated deformations in quaternary glaciolacustrine and glaciodeltaic deposits: examples from central Poland. In: Deformation of Sediments and Sedimentary Rocks (Eds M.E. Jones and R.M.F. Preston), Geol. Soc. Spec. Publ., 29, 279-286.

Cita, M.B. (1982) The Messinian salinity crisis in the Mediterranean: a review. In: Alpine-Mediterranean Geodynamics (Eds H. Berckhemer and K.J. Hsü), Geodyn. Ser., 7, 113-140.

Cita, M.B. and McKenzie, J. (1986) The terminal Miocene event. In: Mesozoic and Cenozoic Oceans (Ed. K.J. Hsü), Geodyn. Ser., 15, 123-140.

Clauzon, G., Suc, J.P., Gautier, F., Berger, A. and Loutre, M.F. (1996) Alternate interpretation of the Messinian salinity crisis: controversy resolved? Geology, 24, 363-366.

Coppier, G., Ott d'Estevou, Ph. and Montenat, C. (1990) Kinematics and paleogeographic evolution of the eastern Almeria basins. Doc. et Trav. IGAL, 12-13, 189-193.

Davenport, C.A. (1994) Geotechnical consequences of ground motion: hazard perspectives. Geologie en Mijnbouw, 73, 339-356.

Davenport, C.A. and Ringrose, P.S. (1987) Deformation of Scottish Quaternary sediment sequences by strong earthquake motions. In: Deformation of Sediments and Sedimentary Rocks (Eds. M.E. Jones and R.M.F. Preston), Geol. Soc. Spec. Publ. 29, 299-314.

DeCelles, P.G. and Cavazza, W. (1995) Upper Messinian conglomerates in Calabria, southern Italy: response to orogenic wedge adjustment following Mediterranean sea-level changes. Geology, 23, 775-778.

Duggen, S., Hoernle, K, van den Bogaard, P. and Harris, C. (2004) Magmatic evolution of the Alboran region: the role of subduction in forming the western Mediterranean and causing the Messinian salinity crisis. Earth Planet. Sci. Lett. , 218, 91-108.

Fortuin, A.R. and Krijgsman, W. (2003) The Messinian of the Nijar Basin (SE Spain): sedimentation, depositional environments and paleogeographic evolution. Sed. Geol., 160, 213-242.

Galli, P. (2000) New empirical relationships between magnitude and distance for liquefaction. Tectonophysics, 324, 169-187.

Griffin, D.L. (2002) Aridity and humidity: two aspects of the late Miocene climate of North Africa and the Mediterranean. Palaeogeogr. Palaeoclimatol. Palaeoecol., 182, 65-91.

Gutscher, M.A., Malod, J., Rehault, J.P., Contrucci, I., Klingelhoefer, F., Mendes-Victor, L. and Spakman, W. (2002)
Evidence for active subduction beneath Gibraltar. Geology, 30, 1071-1074.

Hempton, M.R. and Dewey, J.F. (1983) Earthquake-induced deformational structures in young lacustrine sediments, East Anatolian Fault, southeast Turkey. Tectonophysics, 98, T7-T14.

Hsü, K.J., Montadert, L., Bernouilli, D., Cita, M.B., Erickson, A., Garrison, R.E., Kidd, R.B., Melieres, F., Müller, C. and Wright, R. (1977) History of the Mediterranean salinity crisis. Nature, 267, 399-403.

Huibregtse, P, van Alebeek, H., Zaal, M. and Biermann, C. (1998) Palaeostress analysis of the northern Nijar and southern Vera basins: constraints for the Neogene displacement history of major strike-slip faults in the Betic Cordilleras, SE Spain. Tectonophysics, 300, 79-101.

Jolivet, J., Augier, R, Robin, C., Suc, J-P. and Rouchy, J.M. (2006) Lithospheric-scale geodynamic context of the Messinian salinity crisis. Sed. Geol., 188/189, 9-33.

Jonk, R. and Biermann, C. (2002) Deformation in Neogene sediments of the Sorbas and Vera Basins (SE Spain): constraints on simple-shear deformation and rigid body rotation along major strike-slip faults. J. Struct. Geol., 24, 963-977.

Kanaori, Y., Kawakami, S., Yairi, K. and Hattori, T. (1993) Liquefaction and flowage at archaeological sites in the inner belt of central Japan: tectonic and hazard implications. Eng. Geol., 35, 65-80.

Krijgsman, W., Hilgen, F.J., Raffi, I., Sierro, F.J. and Wilson, D.F. (1999) Chronology, causes and progression of the Messinian salinity crisis. Nature, 400, 652-655.

Krijgsman, W., Fortuin, A.R., Hilgen, F.J. and Sierro, F.J. (2001) Astrochronology for the Messinian Sorbas basin (SE Spain) and orbital (precessional) forcing for evaporite cyclicity. Sed. Geol., 140, 43-60.

Krijgsman, W., Blanc-Valleron, M.-M., Flecker, R., Hilgen, F.J., Kouwenhoven, T.J., Merle, D., Orszag-Sperber, F. and Rouchy, J.M. (2002) The onset of the Messinian salinity crisis in the eastern Mediterranean (Pissouri Basin, Cyprus). Earth Planet. Sci. Lett., 194, 299-300.

Larouzière, F.D. de, Bolze, J., Bordet, P., Hernández, J., Montenat, C. and Ott d'Estevou, Ph. (1988) The Betic segment of the lithospheric Trans-Alboran shear zone during the late Miocene. Tectonophysics, 152, 41-52.

Lourens, L.J., Hilgen, F.J., Zachariasse, W.J., van Hoof, A.A.M., Antonrakou, A. and Vergnaud-Grazzini, C. (1996) Evaluation of the Pliocene to early Pleistocene astronomical timescale. Paleoceanography, 11, 391-413.

Lowe, D.R. (1975) Water escape structures in coarse-grained sediments. Sedimentology, 22, 157-204.

Lu, F.H. (2006) Lithofacies and water-body record of Messinian evaporites in Nijar Basin, SE Spain. Sed. Geol., 188/189, 115-130.

Machour, L., Cornée, J.J., Saint Martin, J.P., Lehmann, P. and Muller, J. (1993) Enregistrement de l'activité séismique dans les sédiments: Exemple des plates-formes carbonatées messiniennes d'Afrique du Nord. Eclogae geol. Helv., 86, 265-281.

Marco, S. and Agnon, A. (1995) Prehistoric earthquake deformations near Masada, Dead Sea graben. Geology, 23, 695-698.

Marín-Lechado, C., Galindo-Zaldivar, J., Rodríguez-Fernández, L.R., Serrano, I. and Pedrera, A. (2005) Active faults, seismicity and stresses in an internal boundary of a tectonic arc (Campo de Dalías and Nijar, southeastern Betic Cordilleras, Spain). Tectonophysics, 296, 81-96. 
Martín, J.M. and Braga, J.C. (1994) Messinian events in the Sorbas Basin in southeast Spain and their implications in the recent history of the Mediterranean. Sed. Geol., 90, 257.

Martinez-Diaz, J. and Hernandez-Enrile, J.N. (2004) Neotectonics and morphotectonics of the southern Almeria region (Betic Cordillera-Spain) kinematic implications. Int. J. Earth Sci, 93, 189-206.

Mather, A.E. and Westhead, R.K. (1993) Plio/Quaternary strain of the Sorbas Basin, SE Spain: Evidence from sediment deformation structures. Quatern. Proc., 3, 57-65.

Mather, A.E., Martin, J.M., Harvey, A.M. and Braga, J.C. 2001. A Field Guide to the Neogene Sedimentary Basins of the Almeria Province, SE Spain. IAS Field Guide, Blackwell Science, Oxford.

Meijer, P. Th. and Krijgsman, W. (2005) A quantitative analysis of the desiccation and re-filling of the Mediterranean during the Messinian Salinity Crisis. Earth Planet. Sci. Lett., 240, 510-520.

Mohindra, R. and Bagati, T.N. (1996) Seismically induced soft-sediment deformation structures (seismites) around Sumdo in the lower Spiti valley (Tethys Himalaya). Sed. Geol., 101, 69-83.

Montenat, C. (1980) Relation entre déformations synsedimentaires et paleoseismicité dans le Messinien de San Miguel de Salinas (Cordillères bétiques orientales, Espagne). Bull. Soc. géol. France, XXII, 501-509.

Montenat, C. and Ott d'Estevou, Ph. (1999) The diversity of Late Neogene sedimentary basins generated by wrench faulting in the eastern Betic cordillera, SE Spain. J. Petrol. Geol., 22, 61-80.

Montenat, C., Ott d'Estevou, P. and Masse, P. (1987a) Tectonic-sedimentary characters of the Betic Neogene Basins evolving in a crustal transcurrent shear zone (SE Spain). Bull. Centre Rech. Explor.-Prod. Elf-Aquitaine, 11, 1-22.

Montenat, C., Ott d'Estevou, P., Larouzière, F.D. and Bedu, P. (1987b) Originalité géodynamique des bassins néogènes du domaine Bétique oriental. Notes et Mém. Total Compagnie Française des Pétroles, 21, 11-49.

Montenat, C., Barrier, P., Ott d'Estevou, Ph. and Hibsch, C. (2007) Seismites: an attempt at critical analysis and classification. Sed. Geol., 196, 5-30.

Moretti, M. and Sabato, L. (2007) Recognition of trigger mechanisms for soft-sediment deformation in the Pleistocene lacustrine deposits of the Sant'Arcangelo Basin (Southern Italy): seismic shocks versus overloading. Sedimentary Geology, 196, 31-45.

Moretti, M., Alfaro, P., Caselles, O. and Canas, J.A. (1999) Modelling seismites with a digital shaking table. Tectonophysics, 304, 369-383.

Neuwerth, R., Suter, F., Guzman, C and Gorin, G.E. (2006) Soft-sediment deformation in a tectonically active area: The Plio-Pleistocene Zarzal Formation in the Cauca Valley (Western Colombia). Sed. Geol., 186, 67-88.

Nichols, R.J., Sparks, R.S.J. and Wilson, C.J.N. (1994) Experimental studies of the fluidization of layered sediments and the formation of fluid escape structures. Sedimentology, 41, 233-253.

Obermeier, S.F. (1996) Use of liquefaction-induced features for paleoseismic analysis - an overview of how seismic liquefaction features can be distinguished from other features and how their regional distribution and properties of source sediment can be used to infer the location and strength of Holocene paleo-earthquakes. Eng. Geol., 44, $1-76$.
Obermeier, S.F., Olson, S.M. and Green, R.A. (2005) Field occurrences of liquefaction-induced features: a primer for engineering geologic analysis of paleoseismic shaking. Eng. Geol., 76, 209-234.

Plaziat, J.C. and Ahmamou, M. (1998) Les différents mécanismes à l'origine de la diversité des séismites, leur identification dans le Pliocène du Saïss de Fès et de Meknès (Maroc) et leur signification tectonique. Geodin. Acta, 11, 183-203.

Plaziat, J.C., Purser, B.H. and Philobos, E. (1990) Seismic deformation structures (seismites) in the syn-rift sediments of the NW Red Sea (Egypt). Bull. Soc. Géol. France, t. VI, 3, 419-434.

Reicherter, K.R. and Reiss, S. (2001) The Carboneras Fault Zone (southeastern Spain) revisited with Ground Penetrating Radar - Quaternary structural styles from high-resolution images. Neth. J. Geosci./Geologie and Mijnbouw, $\mathbf{8 0}$, 129-138.

Reicherter, K.R., Jabaloy, A., Galindo-Zaldívar, J., Ruano, P., Becker-Heidmann, P., Morales, J., Reiss, S. and GonzálezLodeiro, F. (2003) Repeated palaeoseismic activity of the Ventas de Zafarraya fault (S Spain) and its relation with the 1884 Andalusian earthquake. Int. J. Earth Sci., 92, 912-922.

Ricci Lucchi, F. (1995) Sedimentological indicators of paleoseismicity. In: Perspectives in Paleoseismology (Eds L. Serva and D.B. Slemmons). Assoc. Eng. Geol. Spec. Publ. 6, 7-17.

Ringrose, P.S. (1989) Palaeoseismic(?) liquefaction event in late Quaternary lake sediment at Glen Roy, Scotland. Terra Nova, 1, 57-62.

Rodriguez Pascua, M.A. (1997) Paleosismicidad en emplazamientos nucleares. Consejo de Seguridad Nuclear, Madrid, Coleccion Otros Documentos CSN, 3, 286.

Rodríguez-Pascua, M.A., Calvo, J.P., De Vicente, G. and Gómez-Gras, D. (2000) Soft-sediment deformation structures interpreted as seismites in lacustrine sediments of the Prebetic zone, SE Spain, and their potential use as indicators of earthquake magnitudes during the Late Miocene. Sed. Geol., 135, 117-135.

Roep, Th.B., Dabrio, C.J., Fortuin, A.R. and Polo, M.D. (1998) Late highstand patterns of shifting and stepping coastal barriers and washover-fans (late Messinan, Sorbas Basin, SE Spain). Sedim. Geol. 116, 27-56.

Rouchy, J.M. and Caruso, A. (2006) The Messinian sakinity crisis in the Mediterranean basin: A reassessment of the data and an intergrated scenario. Sed. Geol., 188-189, 35-67.

Rouchy, J.M. and Saint Martin, J.P. (1992) Late Miocene events in the Mediterranean as recorded by carbonateevaporite relations. Geology, 20, 629-632.

Seilacher, A. (1969) Fault-graded beds interpreted as seismites. Sedimentology, 13, 155-159.

Seilacher, A. (1984) Sedimentary structures tentatively attributed to seimic events. Mar. Geol., 55, 1-12.

Sierro, F.J., Flores, J.A., Francés Vazquez, A., Utrilla, R., Zamarreno, I., Erlenkeuser, H. and Barcena, M.A. (2003) Orbitally-controlled oscillations in planktic communities and cyclic changes in western Mediterranean hydrography during the Messinian. Palaeogeogr. Palaeoclimatol. Palaeoecol., 190, 289-316.

Sims, J.D. (1973) Earthquake-induced sytructures in sediments of Van Norman Lake, San Fernando, California. Science, 182, 161-163.

Sims, J.D. (1975) Determining earthquake recurrence intervals from deformational structures in young lacustrine sediments. Tectonophysics, 29, 141-152. 
Stapel, G., Moeys, R.P. and Biermann, C. (1996) Neogene evolution of the Sorbas Basin (SE Spain) determined by paleostress analysis. Tectonophysics, 255, 291-305.

Takahama, N., Otsuka, T. and Brahmantyo, B. (2000) A new phenomenon in ancient liquefaction - the draw-in-process, its final stage. Sed. Geol., 135, 157-165.

Van de Poel, H.M. (1992) Foraminiferal biostratigraphy and palaeoenvironments of the Miocene-Pliocene CarbonerasNijar Basin (SE Spain). Scripta Geol., 102, 1-32.

Van de Poel, H.M. (1994) Messinian marginal-marine and continental facies and their stratigraphy in the eastern Almería Province (S.E. Spain). Strata, Actes du Laboratorie de Géologie Sédimentaire et Paléontologie de l'Université Paul Sabatier, Toulouse, Série 2 Mémoires 23, 202-p.
Vanneste, K., Meghraoui, M. and Camelbeeck, T. (1999) Late Quaternary earthquake-related soft-sediment deformation along the Belgian portion of the Feldbiss Fault, Lower Rhine Graben system. Tectonophysics, 309, 5797.

Weijermars, R. (1988) Neogene tectonics in the Western Mediterranean may have caused the Messinian Salinity Crisis and an associated glacial event. Tectonophysics 148, 211-219.

Manuscript received 1 May 2007; revision accepted 17 January 2008 